\title{
5. Sınıf Sosyal Bilgiler Etkin Vatandaşlık Öğrenme Alanı Kazanımlarına İlişkin Eğitim Durumlarının İncelenmesi: Durum Çalışması
}

DOI: $10.26466 /$ opus. 834524

\author{
Mustafa Yeler* - Gürbüz Ocak** \\ * Öğr.Gör., Burdur M. Akif Ersoy Üni. , Eğitim Fakültesi , Burdur/Türkiye \\ E-Posta: myeler@mehmeakif.edu.tr \\ ORCID: 0000-0001-6558-2812 \\ ** Prof. Dr. Afyon Kocatepe Üni. , Eğitim fakültesi , Afyonkarahisar/Türkiye \\ E-Posta: gurbuzocak1@gmail.com \\ ORCID: $\underline{0000-0001-8568-0364}$
}

\section{Öz}

Bu çalışma 5. Sınıf Sosyal Bilgiler Etkinlik Vatandaşlı öğrenme alanı kazanımlarına iliş̧in öğretmeöğrenme sürecindeki etkinliklerin incelenmesi Burdur il merkezinde seçilen bir ortaokulda yapılmıştır. Bunun için nitel araştırma yöntemlerinden durum çalışması modeli ve bütüncül tek durum deseni kullanılmıştır. Araştırma sürecinde veriler her bir kazanım için ayrı düzenlenen ders gözlem formları, gözlemci anekdotları, yarı yapılandırılmış görüşme ve doküman analizi yoluyla toplanmıştır. Bu kapsamda gözlem formuyla elde edilen verilerin çözümlenmesinde gözlenen özelliklerin yeterlik düzeylerine ilişkin puanların ortalamalarl; gözlemci anekdotları ve görüşme ile toplanan verilerde betimsel analiz; ünitelendirilmiş yıllık planda ise doküman analizi kullanılmıştır. Elde edilen verilerin çözümlemesi sonucunda öğretme-öğrenme sürecinde öğretmenin ağırlıklı olarak düz anlatım ve soru cevap yöntemi kullandığı, çoğunlukla ders kitabına bağlı kaldığı, konulara ilişkin bazı bilgileri soru bankasından yazdırdığı, öğretim yöntem -teknik seçiminde kazanımların ve içeriğin özelliklerini dikkate almadığl, zaman yönetimi, iletişim-etkileşim becerilerinde sorunlar yaşadığı, ezberletme, yazdırma, tekrar ettirme ve test sorusu çözdürme vb. uygulamalara yer verdiği gözlenmiştir. Bu sonuçlar doğrultusunda ögrretmen adayların ve öğretmenlerin sorumluluklarında olan Sosyal Bilgiler Öğretim Programlarını en iyi şekilde uygulayabilecek mesleki bilgi beceri, tutum ve değerlere sahip olacak şekilde, yaşantıya dayalı etkinliklerle yetiştirilmesi, hizmet sürecinde de ihtiyaç duydukları çeşitli konularda desteklenmesi ve rehberlik edilmesi önerilmiştir.

Anahtar Kelimeler:

Sosyal bilgiler öğretim programı, etkin vatandaşlık, öğretme-öğrenme süreci, ögretim materyali, program değerlendirme. 


\title{
Investigation of Educational Situations Related to Effective Citizenship Learning Area Achievements in 5th Grade Social Studies Course: A Case Study
}

\begin{abstract}
This study aimed to examine educational situations concerning effective citizenship learning area achievements in 5 th grade Social Studies Course. To this end, case study model and holistic design were used. Data were collected through course observation forms, observer anecdotes, semi-structured interviews, and document analysis organized separately for each objective. The average of the scores related to the proficiency levels of the observed features were used in analyzing the data obtained by the observation form. Descriptive analysis was carried out in the data collected through observer anecdotes and interviews. Finally, document analysis was applied in the unified annual plan. As a result of the analysis of the obtained data, it was observed that the teacher mainly used straight lecturing and question-answer technique, mostly depended on the textbook, get the students write some of the information (regarding the subjects) from question bank books. It was also revealed that the she did not take into account the characteristics of the objectives and the content in the selection of teaching methods and techniques, and she made use of memorization, dictation, repetition and getting the students to solve tests in her teaching. In line with these results, it was suggested that prospective teachers and teachers should be trained in life-based activities to have professional knowledge, skills, attitudes and values to apply Social Studies Curriculum in the best way, and support and guide them in various issues they need in the service process.
\end{abstract}

Keywords: Social studies program, effective citizenship, teaching-learning process teaching material, curriculum evaluation. 


\section{Giriş}

Tüm dünyada eğitim sistemlerinin en temel işlevlerinden biri de kültürel aktarım yoluyla hem bireyin topluma uyumu sağlayacak davranışlar kazandırmak hem de toplumsal devamlılığa hizmet etmektir. Her toplum için kendi benlentilerine uygun vatandaş yetiştirme çabası ağır basmaktadır. Her eğitim sistemi ait oldukları toplumlarda bu işlevleri ders öğretim programları aracılığıyla gerçekleştirir. Dünyada ve Türkiye'de bu amaca hizmet eden en temel ders öğretim programlarından biri de Sosyal Bilgilerdir (Milli Eğitim Bakanlığı, MEB, 2004; Safran, 2011).

Sosyal Bilgiler dersinin, Sosyal Bilgiler Ulusal Konseyi (National Curriculum Social Studies, NCSS, 1994 ve 2010) tarafından “... kültürel çeşitliliğe ve demokratik topluma uygun, etkin vatandaşlar olarak bireylerin yetişmelerini amaçladığ 1 ve bu çerçevede öğrencilere bilgi, eleştirel düşünme yeteneği ve deneyimler kazandırmaya ve geliştirmeye hizmet ettiği vurgulanmaktadır. Türkiye'de ise MEB (2005), Sosyal Bilgileri, “....çeşitli disiplinlere ait öğrenme alanlarının bir ünite ya da tema altında birleştirilmesini içeren; insanın sosyal ve fiziki çevresiyle etkileşiminin geçmiş, bugün ve gelecek bağlamında incelendiği; toplu öğretim anlayışından hareketle oluşturulmuş bir ilköğretim ders" olarak tanımlarken; Sönmez (2008) de Sosyal Bilgileri, toplumsal gerçek ile kanıtlamaya dayalı çok disiplin alanıla ilişki kurma ve bu süreçte elde edilen dirik bilgiler bütünü görmektedir. Barr, Barth ve Shermis (1977)'e göre ise Sosyal bilgiler, vatandaşlık eğitimi amacına yönelik olarak insan ilişkileriyle ilgili bilgi ve deneyimlerin biraraya getirilmesidir.

$\mathrm{Bu}$ bilgiler çerçevesinde özetle Sosyal Bilgiler, disiplinlerarası bir yaklaşımla, bireyi en yakından en uzak çevresine doğru etkileyen fiziki ve sosyal her ortamda etkin olmasına yönelik bilgi ve beceriler kazandırmayı amaçlayan bir alan olarak tanımlanabilir. Nitekim etkin vatandaşlık amacıyla tüm sosyal bilimlerden seçilen bilgiler birleştirilerek bir program oluşturulmuştur. Bu programda sosyal bilim dallarının sınırları kaldırılmış ve bütüncül bir program anlayışı benimsenmiştir (Doğanay, 2008). Görüldüğü gibi Sosyal Bilgiler tanım ve içerikleri etkin vatandaş kavramını öne çıkarmakla birlikte etkin vatandaşın değişen ülke ve dünya koşullarına uygun yetiştirilmesi gerekliliği vurgulanmaktadır. Etkin vatandaşlık devlet ve birey arasındaki ilişkileri ve hak ve sorumlulukları kapsar. Etkin vatandaş 
olabilmenin koşulları için gerekli olan bilgi, beceri ve değerlerin bireylere kazandırılması genel olarak tüm eğitim sisteminin genel amacı olmakla birlikte, ders öğretim programları içinde bu sorumluluk daha çok Sosyal Bilgiler dersinin kapsamındadır (Kılıçoğlu, 2009; Tay, 2017). Bu nedenle de Sosyal Bilgiler, toplumun bir parçası olarak bireyin sosyalleşmesini ve yaşamla ilgili sorunlarla başetmesini bilen, yaşadığı toplumun kültür, tarih ve değerlerini özümseyen öğrendiği bilgileri kullanabilen, üretken ve sorgulayan, vatandaşlık görevlerinin ve yaşadığı dünyadaki gelişmelerin farkında olan insanlar yetiştirmeyi görev edinmiştir (Yeşiltaş, 2006). Dolayısıyla da Sosyal Bilgiler dersi ile etkin vatandaşlık öğretimi arasında organik bir bağdan söz edilebilir.

Bu bağlamda Türkiye'de Sosyal Bilgiler dersi ile Vatandaşlık eğitimi arasında yakın tarihsel süreçte çeşitli uygulamalar gözlenmiştir. Örneğin, Türkiye'de 1995 yılında Vatandaşlık Bilgileri dersiyle doğrudan vatandaşlık ve insan hakları eğitimi hayata geçmiştir. Ancak Vatandaşlık Bilgileri dersi daha sonra 2004-2005 yılında değişen program anlayışıyla uygulamadan kaldırılarak, bu dersin içeriği Sosyal Bilgiler dersinin kapsamına alınmıştır. 2010 yılında Vatandaşlık ve Demokrasi Eğitimi adıyla yeni bir ders halinde düzenlenmiş, ancak bu kez de 2012 yılındaki kesintili zorunlu eğitim $(4+4+4)$ uygulaması ile tekrar yürürlükten kaldırılmıştır (MEB, 2012).

Günümüzde hemen her toplumda küreselleşme ve teknolojik gelişmeler çerçevesinde bireysel ve toplumsal hayata yönelik çok yönlü ve köklü değişmeler meydana gelmektedir. Bu değişmelere paralel olarak her ülkenin en başta eğitim sisteminin tüm öğelerinde, özellikle de eğitim sisteminin işleyişinin temel ögelerinden olan öğretim programlarının günün ihtiyaçlarına cevap verecek şekilde güncellemeler yapılması gereği ortaya çıkmaktadır. Bir başka deyişle, her ülke için öğretim programlarının değişen koşullara uygun hale getirilmesi bir zorunluluk haline gelmektedir (Tay, 2017). Bu kapsamda Türkiye'de de 2017 yılında MEB tarafından toplumsal, ekonomik, bilim ve teknolojik gelişmeler, bireysel ihtiyaçlara dikkat çekilerek uluslararası boyutta yapılan sınavların sonuçları, kalkınma planları, kurum ve kuruluşlar tarafindan hazırlanan raporlar, hükümetlerin eylem planları ile bilimsel araştırmalardan elde edilen verilere dayanılarak tüm öğretim programları yenilenmesi çalışmaları yapılmıştır (MEB, 2017). Bu çalışmalar kapsamında güncellenen öğretim programlarından biri de Sosyal Bilgiler Dersi Öğretim Programı (SBDÖP) olup içeriğine de ilk kez "Etkin 
Vatandaşlık Öğrenme Alanı (EVÖA)" eklenmiştir (Çoban ve Akşit, 2018 ; Tay, 2017).

Her ülke, eğitim sisteminde vatandaşlık eğitimini neden ve nasıl vereceğine ilişikin kararlar vermek ve tercihlerde bulunmak durumundadır. Bu açıdan bakıldığında vatandaşlık eğitiminin içeriği ve nitelikleri her ülkede vatandaşlığa yüklenen anlama, beklentilere, ulusal ve uluslararası koşullara paralel olarak farklılık göstermektedir. Şen (2019)'e göre tarihsel süreç içerinde küresel ve ulusal düzeyde birçok faktörün etkisiyle vatandaşlık eğitimi; geleneksellikten modern vatandaşlık eğitim anlayışına doğru bir dönüşüm sergilemiş olup modern vatandaşlık eğitimi de kendi içinde çokkültürlü, eleştirel, post-yapısalcı, demokratik ve hümanist vatandaşlık eğitim anlayışları olarak sınıflandırılmaktadır. Bu bağlamda vatandaşlık eğitimi günümüzde yalnızca bilgi aktarımına dayalı ve sadece bireyin yaşadığı toplumla sınırlı kalması gerektiği anlayışından oldukça uzaklaşmıştır. Bu anlayışın aksine çağdaş vatandaşlık eğitimi bireylerin hem toplumsal yaşamla hem de küresel ölçekteki hak ve görevlerini bilinçli olarak yerine getirmelerine özen gösterilmesi anlayışını öne çıkarmaktadır. Bu anlayış çerçevesinde yetiştirilen etkili bir vatandaşın özellikleri nelerdir? sorusuna cevap olarak NCSS (2012), bu vatandaşların niteliklerini belirlemiştir. Buna göre etkili bir vatandaş:

- Demokratik değerleri kabul edip bunları yaşamında kullanan,

- Kendine ve çevresine faydalı olmak için sorumluluklarını yerine getiren,

- İnsanları, ulusunu, dünyayı ve kültürel özellikleri tanıyan,

- Ülkesinin vatandaşlık birimlerini ve politik süreçlerini tanıan,

- Yerel, bölgesel, ulusal ve küresel seviyedeki insanları etkileyen olay ve faaliyetlerin farkında olan,

- Bilinçli fikir ve yaratıcı çözümler geliştirmek için çeşitli kaynak ve bakış açılarını araştıran,

- Anlamlı sorular soran, bilgi ve fikirleri değerlendirebilen ve analiz edebilen,

- Toplumsal ve özel yaşayışta etkili karar verme ve problem çözme becerilerini kullanan,

- Bir grup üyesi olarak işbirliği içinde etkili bir şekilde çalışabilen,

- Vatandaşlık ve toplum yaşamına aktif olarak katılan bireylerdir.

$\mathrm{Bu}$ nitelikler incelendiğinde 2004-2005 öğretim yılından itibaren Türkiye'de hayata geçen Yapılandırmacı eğitim anlayışının paradigmasının ve 
bireylere kazandırmak istediği temel niteliklerle, Sosyal Bilgiler öğretimi ve etkin vatandaşlık eğitim anlayışlarının büyük bir oranda örtüştüğünü çok açı bir şekilde görmek mümkündür. Çünkü 2004 ve 2018 SBDÖP’ları Yapılandırmacı eğitim anlayışını temele alarak öğrenciyi merkeze alan, bilginin hazır verilmesi yerine öğrenci tarafından oluşturulması ve güncellenmesini amaçlayan, ne kadar öğrenildiğinden çok niçin ve nasıl öğrenildiğine odaklanır. Öğretmenin öğretme-öğrenme etkinliklerinde hazır bilgi sunan değil, öğrencilerin yapabilecekleri düzeydeki etkinlikler öğrencilerin daha çok sorumluluk aldığı, öğrenci düşüncelerinin desteklendiği ve anlamlı öğrenmeyi gerçekleştirecek bireylerin çevreleriyle daha fazla etkileşimde bulunmalarına ve zengin öğrenme yaşantıları geçirmelerini sağlayacak, dolayısıyla da özgün bir öğrenme ortamı hazırlamasını öngörmektedir (Gündoğdu, 2010; Yaşar, 1998). Bu temel özellikler çerçevesinde öğrenci merkezli öğretim yöntemleri olarak da aktif öğrenme, işbirlikli öğrenme, yapılandırmacılık, çoklu zekâ, sorgulamaya dayalı öğrenme, probleme dayalı öğrenme, proje tabanlı öğrenme, sorgulayıcı öğrenme, buluş yoluyla öğrenme yaklaşımları öne çımaktadır (Açıkgöz, 2003; Kaya, 2008).

Türkiye'deki SBDÖP değerlendirilmesi ile ilgili alanyazın incelendiğinde bu alanda çok sayıda çalışma yapıldığı görülmektedir. SBDÖP'nın öğeleri açısından ele alındığında kazanımlar (hedefler), içerik, öğretme-öğrenme süreci ve ölçme değerlendirme boyutlarında çalışmalar gözlenmiştir. SBDÖP'nın anlayışı ve genel özellikleri ile ilgili olarak Çetin (2007) ve Ekinci (2007) öğretmenlerin programı, yapılandırmacı anlayışa dayalı, öğrenci merkezli buldukları, ancak sınıf mevcutlarının fazlalığı, ders materyallerinin eksikliği vb. nedenlerle öğretme-öğrenme süreçlerinde olumsuzluklar yaşadıklarını; (Kabapınar ve Ataman, 2010; Kalaycıoğlu, 2007; Kuyucu, 2007; Taş ve Kıroğlu 2018) zaman yönetimi ile sorunlarını; Arslan ve Demirel (2007) öğretmenlerin geleneksel yöntemleri kullanmaya devam ettiklerini, Yaşar (2005) programların öğrenci merkezli olmasına rağmen, öğrenciye yeterince seçme şansı verilmediğini ve öğretmen ağırlığının devam ettiğini vurgulamaktadırlar.

Sosyal Bilgiler öğretmenlerinin öğretim süreci yeterlikleri ise (Akpınar, Çolak ve Yiğit, 2012: Yeşil 2016) tarafından ele alınmış; öğretmen ve öğretmen adaylarının öğretim sürecindeki yöntem teknik seçimi ve kullanma, materyal kullanma, iletişim ve sınıf yönetimi boyutlarında yetersizlikler tespit 
etmişlerdir. Öte yandan Akpınar ve Gezer, 2010; Arslan ve Demirel, 2007; Döner 2019; Frrat Durdukoca, 2018; Özkan, 2016; Ünal, 2012) öğretmenlerin öğrenen merkezli yeni eğitim yaklaşımlarını, fikir olarak benimsediklerini, ancak öğretim süreci uygulamalarına bunu yansıtmayarak ağırlıklı olarak geleneksel anlatımla ders işlemeyi sürdürdükleri sonucuna ulaşmıştır. Bu çalışmaların yanında Sosyal Bilgiler öğretimiyle ilgili yapılan araştırmalarda öğretmelerin, SBDÖP programındaki kazanım sayılarının fazla oluşu, program içeriğinin yoğunluğu, süre yetersizliği, materyallerin olmaması, strateji, yöntem-teknik kullanımı ve öğrenci hazırbulunuşlukları ile ilgili sorunların tespit edildiği sonuçlara ulaşılmıştır (Çalışkan 2010; Dinç ve Doğan, 2010; Doğanay ve Sarı, 2008; Karacaoğlu ve Acar, 2010; Polat, 2006; Okobia, 2016). Ayrıca Aykaç (2007) tarafından programda hazırlanan etkinliklerin öğrenciyi aktif kılmadığı, bireysel farklılıklar ile bölgesel farklılıkları dikkate almadığın ifade edilmiştir.

SBDÖP'ının yeni bir öğesi olarak EVÖA özelinde ise alanyazında vatandaşlık eğitimindeki değişiklikler (Şen, 2019; Dumitriu ve Dumitru, 2014); öğretim programları ve ders kitapları açısından vatandaşlık eğitiminin boyutları, sorunları, uygulama süreçleri ilgili olarak (Avcı ve Faiz, 2018; Çolak, 2015; Davies ve Chong, 2016, Ekici, 2018; İnce, 2012, Kennelly ve Llewellyn, 2011, Navarro-Medina ve Alba-Fernandez, 2015, Osler ve Starkey, 2009; Sigauke,2012; Turan, 2019); etkin vatandaşlık eğitimi ve uygulamalarına ilişkin öğretmenlerin ve öğretmen adaylarının deneyimleri, alg1 ve görüşleri, programı tanıma yeterlikleri (Çiçek, 2018, Genç ve Çelik, 2018, Genç, 2018, İkinci, 2018, Şimşek, T1kman, Yıldırım ve Şentürk, 2017; Şimşek, 2017; Willemse, Ten Dam, Geijsel, Van Wessum, Volman, 2015) tarafindan ele alınmıştır. Bu çalışmalarda vatandaşlık eğitimiyle ilgili eğitim yaklaşımları, öğretmen nitelikleri, öğretim programlarının ve uygulamalarına ilişkin yetersizliklerden söz edilmektedir.

Alanyazındaki yukarıdaki araştırmaların bulguları dikkate alındığında özetle MEB tarafından SBDÖP'da yapılan değişimlerin istenilen sonucu yaratmadığı ya da bu öğretim programlarının olması gerektiği gibi uygulanamadığı düşünülmektedir. Ayrıca alanyazındaki genelde SBDÖP’larının özelde ise EVÖA'nın değerlendirmelerine yönelik çalışmaların ağırlıklı olarak ya öğretmen ve öğrenci görüşlerine dayalı ya da program metinleri üzerinde doküman analizi şeklinde olduğu tespit edilmiştir. Bununla birlikte 
söz konusu araştırma bu süreçlerinde veriler ağırlıklı olarak dolaylı veri toplama araçları kullanılarak elde edilmiştir. Halbuki bir programın etkililiğine ve işe yararlığına ilişkin kararlar verebilmek için tüm öğelerinin bütüncül şekilde ele alınması kadar Stufflebeam'in Bağlam, Girdi, Süreç ve Ürün (CIPP) Modelinde öğretme-öğrenme sürecinde kazanımları gerçekleştirmek üzere hangi etkinliklerin nasıl yapıldığını, süreçteki diğer değişkenlerin nasıl işe koşulduğunun belirlenmesi gerekir. Bu açıdan bakıldığında alınyazındaki çalışmaların uygulama koşullarının dikkate alınmaması nedeniyle eksiklikler içerdiği düşünülmektedir. Bir başka deyişle program değerlendirme çalışması yapan araştırmacıların sahada öğretme-öğrenme ortamları doğrudan ve tüm yönleriyle ele almaları gerektiği önemli görülmektedir.

\section{Amaç}

$\mathrm{Bu}$ nedenler bağlamında bu araştırmanın amacı, SBDÖP'nın öğretmeöğrenme süreçlerinin temel öğelerinin nasıl işe koşulduğunu ve bu sürecin niteliklerini kendi doğal ortamında doğrudan belirlemektir. Bunun için 5 . Sınıf SBDÖP'da ilk kez yer alan SB-EVÖA'nına ilişkin kazanımlara ulaşılması için öğretme-öğrenme sürecinde işe koşulan değişkenlerin özelliklerini, hangi öğretim etkinlerinin nasıl yapıldığını, kullanılan öğretim materyallerinin tür, özellik ve kullanım biçimlerini, öğretmenin bu öğrenme alanıyla ilgili olarak planladıklarını ne kadar ve ne şekilde öğretme-öğrenme ortamına yansıtabildiğini bütüncül olarak ortaya çıkarmaktır. Bu amaçlara yönelik olarak araştırma sürecinde aşağıdaki sorulara cevap aranmıştır.

\section{Alt Problemler}

1. 5. Sınıf (SB- EVÖA) öğretme-öğrenme sürecindeki kullanılan öğretim yöntem-tekniklerinin temel özellikleri nasıldır?

2. 5. Sınıf SB- EVÖA'ının öğretme-öğrenme sürecindeki kullanılan materyallerin nitelikleri nasıldır?

3. 5. Sınıf SB-EVÖA'nın öğretme-öğrenme sürecindeki etkinliklere yönelik gözlemci anekdotları nelerdir?

4. Sınıf SB- EVÖA ile ilgili olarak öğretmenin ünitelendirilmiş yıllık planı nasıl düzenlemiştir? 
5. Sınıf SB-EVÖA'nındaki öğretme-öğrenme etkinlikleri ile ilgili olarak öğretmenin görüşleri nelerdir?

\section{Yöntem}

Bu çalışma, SB- EVÖA'nına ilişkin öğretme-öğrenme ürecini kendine özgü koşulları içinde tüm yönleriyle incelemek amaciyla nitel araştırma modellerinden durum çalışması olarak planlanıp yürütülmüştür. Durum çalışması alanyazında sınırlı bir sistemin nasıl işlediği ve çalıştığı hakkında sistematik ve bilgi toplamak için çoklu veri toplama (gözlem, görüşme, doküman analizi vb.) kullanılarak o sistemin derinlemesine incelenmesini içeren duruma bağlı temaların tanımlandığı nitel bir araştırma yaklaşımı olarak tanımlanmaktadır (Creswell, 2007; Chmiliar, 2010; Merriam, 2013; Akt. Subaşı ve Okumuş, 2017). Bu araştırma için seçilen EVÖA'nın hem öğretme-öğrenme süreci etkinliklerine ilişkin çoklu veri toplayarak süreçteki birçok değişkeni bütüncül şekilde incelemek hem de bu öğrenme alanının SBDÖP’larında ilk kez yer alması nedeniyle bütüncül tek durum deseni kullanılmıştır. Bu desende hem bir tek durumu birden fazla veri toplama arac kullanarak derinlemesine inceleme hem de daha önce çalışılmamış bir alanda yeni bilgilere ulaşabilme imkânı bulunmaktadır (Yin, 2017). Bu bağlamda bu çalışma 2018-2019 öğretim yılı bahar döneminde seçilen çalışma grubundaki katılımcılarla 18 ders saati süresince gerçekleştirilen EVÖA öğrenme alanı etkinlikleriyle sinurlıdır.

\section{Araştırmanın yapıldığı sınıfa ve eğitim ortamına ilişkin bilgiler}

Araştırmada gözlem grubu olarak seçilen sınıf, amaçlı örnekleme yöntemlerinden "kolay ulaşılabilir örnekleme" kullanılarak belirlenmiştir. Yıldırım ve Şimşek (2011)'e göre bu örnekleme yönteminde araştırmacı kendine yakın olan ve erişilmesi kolay olan bir durumu seçer. Bu durum çalışmaya hız ve kolaylık katar. Bu çerçevede çalışma için SBDÖP’ı belirlendikten sonra bu branştaki Burdur il merkezindeki bazı öğretmenlerle görüşülmüş, çalışmanın amacı ve içeriği anlatılmıştır. Bu aşamadan sonra, konuya ilgi gösteren öğretmenlerin haftalık ders programları ile araştırmacı grubun haftalık ders saatlerinin uyuşması, okul idaresinin destekleyici yaklaşımı, ulaşım kolaylığı vb. nedenler dikkate alınarak Burdur ilinde orta sosyo-ekonomik düzeyde 
öğrencilerin bulunduğu bir ortaokulun 5. sınıfı seçilmiştir. Çalışma grubu olarak belirlenen bu sinıfta, 14 kız, 3 erkek olmak üzere toplam 17 öğrenci ve mesleğinde 17. yılını çalışan bir kadın öğretmen bulunmaktadır.

Araştırmanın yapıldığı sınıf, mekân olarak $15 \mathrm{~m}^{2}$ boyutundadır. Sınıfta toplam 12 sıra olup sıralar arka arkaya dizilmiştir. Bu haliyle sınıftaki sıralarının sayısı, sınıf mevcuduna göre oldukça yeterliydi. Sınıftaki öğrenciler sıralarda genel olarak ikili, bazı öğrenciler ise tek olarak oturuyordu. Dolayısıyla her öğrenci, oturduğu sıra itibariyle tahtaya yakındı. Sınıf fiziksel boyut olarak çok büyük olmamasına rağmen, öğrenci sayısı için yeterli, güneş ışığı alan ve duvarları bej renkli boya ile boyalı idi. En arkada kütüphane olarak adlandırılan bir kitaplık vardı, ama içinde çok fazla kitap yoktu. Matematik dersine yönelik birkaç oyun materyali vardı. Sınıftaki bilgilendirme panosunda ise önemli gün ve haftalarla ilgili daha çok akademik düzeyde bilgisayar çıktısı yazılı metinler bulunmaktaydı. Onun dışında öğrencinin ilgisini ve dikkatini derse çekecek materyaller yoktu. Bunun yanında sınıfta akıllı tahta vardı, ancak öğretmen tarafından çok kullanmiyordu.

Sosyal açıdan ele alırsak sınıfta kız öğrenciler sayıca daha fazlaydı ve kendi aralarında iki gruba ayrılmış durumdaydılar. Ancak aralarında herhangi bir çatışma ve sorun gözlenmemiştir. Arkadaşlık ilişkileri açısından kızlar ve erkekler arasında iyiydi. Erkekler ve kızların arasında bir cinsiyet ayrımı davranışlarına rastlanmamıştır. Fakat sadece sınıfta özel eğitim gereksinimi olan bir öğrenci oldukça fazla dışlanıyordu. Tüm sınıf bu öğrencinin dengesiz tutum ve tavırlarından korktukları için onu aralarındaki oyunlara ve sohbetlere dahil etmiyorlardı. Söz konusu öğrencide bu duruma oldukça üzülüyor ve bu tepkisini arkadaşları ile kavga ederek gösteriyordu.

\section{Veri Toplama Araçları}

$\mathrm{Bu}$ araştırma için sınıfın öğretim ortamı gözlenmiş, öğretmenle görüşme yapılmış ve öğretmenin yıllık planı incelenmiştir. Veri çeşitlemesinin yapıldığı çalışmada gözlem formları ile gözlem yapılmış, yarı yapılandırılmış görüşme ile öğretmenin görüşü alınmış ve doküman olarak yıllık plan incelenmiştir. Bu bölümde kullanılan veri toplama araçlarına ilişkin bilgiler verilmiştir.

\section{a. Gözlem}


Bu çalışmada kazanımlara ve uzman görüşlerine göre geliştirilen gözlem formları kullanılarak araştırmacı tarafından veri toplanmıştır. Gözlem, araştırma konusu hakkında bilgi toplamak için nesneler, olaylar ve durumların sistematik bir biçimde izlenerek betimlenmesidir (Gürbüz ve Şahin, 2011). Bailey (1982)'ye göre ise gözlem, herhangi bir ortamda ya da kurumda oluşan davranışı ayrıntılı olarak tanımlamak amaciyla kullanılan bir yöntemdir (Akt. Şimşek ve Yıldırım, 2011). Bu araştırma sürecinde gözlem, sınıf içinde sistemli ve gözlemci katılımcı olarak kullanılmıştır.

Sınıf içi gözlemlerde kullanmak üzere 5. Sınıf SB- EVÖA'ında kazandırılması öngörülen dört kazanım için ilk Bloom Taksonomisine göre düzeyleri dikkate alınarak her bir kazanıma ait öğrenci davranışları tanımlanmıştır. Bu davranışların kazanılması için uygun olan ve Sosyal Bilgiler'de yaygın olarak kullanılan öğretim yöntem ve teknikleri (ÖYT) ile öğretim materyalleri (ÖM) belirlenmiştir. Daha sonra ÖYT'ler sayı ile; ÖM'ler de harfle kodlanarak alfabetik sıraya konularak Tablo 1'de verilmiştir.

Tablo 1. Ders gözlem formunda yer alan ÖYT ile ÖM listesi

\begin{tabular}{|c|c|c|c|}
\hline Kod & Öğretim Yöntem ve teknikleri & Kod & Öğretim materyalleri \\
\hline 1 & Akvaryum & A & Akıllı tahta \\
\hline 2 & Altı şapkalı/Ayakkabılı & $\mathrm{B}$ & Anlam çözümleme /karşılaştırma tabloları \\
\hline 3 & Anlatım & $\mathrm{C}$ & Bilgisayar, tablet vb kullanımı \\
\hline 4 & Beyin firtınası & $\mathrm{D}$ & Bilmece, bulmaca \\
\hline 5 & Drama & E & Çalışma yaprağı \\
\hline 6 & Gezi & $\mathrm{F}$ & Ders kitabı kullanma \\
\hline 7 & Görüş geliştirme & G & Gazete ve dergilerden yararlanma \\
\hline 8 & Gösterip Yaptırma & $\mathrm{H}$ & İnternet kullanımı \\
\hline 9 & Gözlem & $\mathrm{I}$ & Karikatür, fikra, mizah \\
\hline 10 & İstasyon & $\dot{\mathrm{I}}$ & Kavram haritaları (zihin, bilgi, balık kılçı̆̆ı vb.) \\
\hline 11 & Kartopu & $\mathrm{J}$ & Kaynak kişi / yetkili kişi \\
\hline 12 & Konuşma halkası & $\mathrm{K}$ & Öykü, şiir, masal, destan \\
\hline 13 & Metafor /anoloji & $\mathrm{L}$ & Projeksiyon \\
\hline 14 & Ödev & $\mathrm{M}$ & Ritim, müzik, akrostij \\
\hline 15 & Örnek olay & $\mathrm{N}$ & Sosyal medya kullanımı \\
\hline 16 & Proje & $\mathrm{O}$ & Şekil, Şema, grafik, resim \\
\hline 17 & Rol oynama & Ö & Üç boyutlu materyal (maket) \\
\hline 18 & Soru cevap & $\mathrm{P}$ & Video, film izleme \\
\hline 19 & Tartışma & $\mathrm{R}$ & Yazı tahtası \\
\hline \multirow[t]{2}{*}{20} & Diğer Aktif öğrenme teknikleri & $\mathrm{T}$ & Gerçek nesneler \\
\hline & & $\mathrm{S}$ & Diğer \\
\hline
\end{tabular}

*Listeler alfabetik olarak stralanmıştır 
$\mathrm{Bu}$ aşamadan sonra maddelerin düzeylerini belirmek üzere "çok yeterliden çok yetersize" doğru beşli dereceleme oluşturulmuş; gözlemcilerin kazanıma ait her bir davranış için yöntem-teknik ve materyallerin kullanılma yeterlilik düzeylerini işaretleyebilecekleri form oluşturulmuştur. Bu formun geliştirilmesinde Sosyal Bilgiler eğitimi alanında iki öğretim üyesinden, Eğitim Programları ve Öğretim ile Ölçme Değerlendirme alanında da birer olmak üzere toplam dört uzmandan yardım ve görüşler alınmıştır.

Geliştirilen bu gözlem formlarının kullanıldığı gözlem sürecinde, araştırmacı ile birlikte Sosyal Bilgiler öğretmenliği 4.sınıfta öğrenim gören ve öğretmenlik uygulaması-2 dersini alan iki öğretmen adayı da gözlemci olarak yer almıştır. Gözlemci olarak sürece katılan bu öğretmen adayları süreç hakkında ve kullanılan gözlem formları konusunda araştırmacı tarafından bilgilendirilmiştir. Bu çalışma kapsamında gözlenen kazanımlar ve gözlem süreleri Tablo 2.'de verilmiştir:

Tablo 2. Gözlenen kazanımlar ve gözlem süreleri

\begin{tabular}{ll}
\hline Kazanımlar & $\begin{array}{l}\text { Gözlem süresi } \\
\text { (Ders saati) }\end{array}$ \\
\hline $\begin{array}{l}\text { SB.5.6.1. Bireysel ve toplumsal ihtiyaçlar ile bu ihtiyaçların karşılanması için hizmet } \\
\text { veren kurumları ilişkilendirir }\end{array}$ & 6 \\
\hline SB.5.6.2. Yaşadığı yerin yönetim birimlerinin temel görevlerini açıklar. & 6 \\
\hline SB.5.6.3. Temel hakları ve bu hakları kullanmanın önemini açılar. & 3 \\
\hline $\begin{array}{l}\text { SB.5.6.4. Millì egemenlik ve bağımsızlık sembollerimizden Bayrağımıza ve İstiklâl } \\
\text { Marşına değer verir }\end{array}$ & 3 \\
\hline Toplam & 18 \\
\hline
\end{tabular}

Tablo 2'de görüldüğü gibi gözlem süreci birinci ve ikinci kazanım için 6, diğer kazanımlar ise $3^{\prime}$ er ders saati olmak üzere toplam 18 ders saati olarak gerçekleştirilmiştir.

\section{b. Gözlemci anekdotlar}

Veri toplama sürecinde gözlemcilerin, sınıf ortamında her kazanıma ait etkinliklere ilişkin gözlem formunda öngörülmeyen eylemleri ve durumları tespit etmek için ayrıca not tutmaları istenmiştir. Gözlemciler tarafından alınan bu notlar her hafta dersin sonunda toplanmıştır. 


\section{c. Görüşme}

Bu çalışmada veri çeşitlemesinin bir ayağı olan görüşme, dersin öğretmeni ile yapılmıştır. İnsanların deneyimlerini ve bu deneyimleri nasıl anlamlandırdıklarını anlamaya çalışmak görüşmenin bu temel amacı çerçevesinde yapılan görüşme "görüşme formu" kullanılarak gerçekleştirilmiştir.

$\mathrm{Bu}$ nedenle görüşme, insanların öyküleri, betimlemeleri ve düşüncelerine odaklanır. Bizim dışımızdaki insanların sosyal gerçekliği nasıl anlamlandırdıklarını öğrenmek oldukça güçtür. Farklı kişilerin olgu ve olayları anlayış, kavrayış ve değerlendiriş tarzları farklıdır ve kendilerine özgüdür. Bu farklılık araştırmacıları diğer insanların öznel dünyalarını sistematik olarak incelemeye yöneltmiştir. Öğretmen, öğrenci ya da okul yöneticisi gözlenerek onların davranışlarına ulaşılabilir. Ne var ki, görüşme ile davranışların ve kişilerin eylemlerinin bağlamındaki nedenleriyle daha bütünsel anlaşılması mümkündür (Seidman, 1991; Akt. Türnüklü, 2000). Bu çalışmada veri toplama aracı olarak "yarı yapılandırılmış görüşme" kullanılmıştır.

Bu çalışmada görüşme, dersin öğretmeni ile yapılmıştır. Bunun için Sosyal Bilgiler Eğitimi ve Eğitim Programlanı ve Öğretim alanında uzman iki öğretim elemanının yardım ve desteği alınarak araştırmanın amacı ve alt problemleri doğrultusunda ders öğretmeninin, öğretme-öğrenme süreci değişken ve etkinliklerini planlama, uygulamalarına ilişkin tercih ve görüşlerini belirlemeye hizmet edecek yarı yapılandırılmış aşağıda verilen altı soru belirlenmiştir. $\mathrm{Bu}$ sorular hazırlanırken araştırmanın amacına hizmet etmesinin yanı sıra dil ve anlatım yönünden anlaşılırlığı, içeriklerinin netliği, görüşmeci üzerindeki psikolojik etkileri, cevaplama konusunda yönlendirici olmaması ya da kısa cevaplarla geçiştirilmemesi gibi hususlar dikkate alınmıştır. Bu hususları kontrol etmek için söz konusu görüşme soruları MEB'de görev yapan iki Sosyal Bilgiler öğretmeniyle pilot uygulama yapılmıştır. Bu işlemlerden sonra karar verilen ve görüşme sürecinde kullanılan sorular şunlardır:

1. Derslerinize genel olarak ne tür bir öğretim yolu izliyorsunuz?

2. Derslerinizde ne tür öğretim etkinliklerini, nasıl kullanıyorsunuz?

3. Öğretim etkinliklerinizde kazanım düzeylerini nasıl dikkate alıyorsunuz?

4. Ders işleme sürecinde öğrencilerinizi etkin kılmak için dersin öğretim sürecinde neler yapiyorsunuz? 
5. Derslerinizde hangi öğretim yöntem-tekniklerini kullanıyorsunuz? Gerekçeleri nelerdir?

6. Derslerinizde hangi öğretim materyallerini kullanıyorsunuz? Gerekçeleri nelerdir?

Öğretmenin bu sorulara verdiği cevaplar doğrultusunda araştırmacı tarafından sonda amaçlı sorular sorularak elde edilen verilerde derinlik sağlama amaçlanmıştır. Tüm görüşme süreci ses kayıt cihazına alınmıştır.

\section{d. Doküman analizi}

$\mathrm{Bu}$ araştırmada doküman olarak öğretmenin 5. Sınıf Sosyal Bilgiler dersi için yaptığı ve okul idaresine onaylattığ ünitelendirilmiş yıllık plan incelenmiştir. Söz konusu bu planın "SB- EVÖA'inda" yer alan kazanımlar, süre, yöntem teknik vb. öğeler açısından ele alınarak taşıdığı nitelikler belirlenmiştir.

\section{Verilerin Çözümlenmesi}

Bu araştırma sürecinde kullanılan çeşitli veri toplama araçlarıyla elde edilen veriler ayrı ayrı analiz edilmiştir. Bu kapsamda araştırmadan gözlem formuyla elde edilen verilerin çözümlenmesinde gözlenen özelliklerin yeterlik düzeylerine ilişkin puanların ortalamaları; gözlemci anekdotları ve görüşme ile toplanan verilerde betimsel analiz; ünitelendirilmiş yıllık planda ise doküman analizi kullanılmıştır. Bu bölümde araştırma sürecinde elde edilen verilerin analizinde izlenen süreçler ve işlemler sırasıyla açılanmıştır:

\section{a. Gözlem verilerinin çözümlenmesi}

SB- EVÖA'ındaki her bir kazanım için hazırlanan gözlem formuyla elde edilen veriler yine sadece o kazanımla sınırlı olacak şekilde incelenmiştir. $\mathrm{Bu}$ çerçevede gözlenen kazanımı öğretmek için gerçekleştirilen öğretmeöğrenme süreci etkinliklerinde kullanılan öğretim yöntem ve teknikleri ile öğretim materyallerinden hangilerinin kullanıldığını ve yeterlilik düzeylerine ilişkin üç gözlemcinin formlarında tespit ettikleri görüşlerin derece puanlarının ortalaması alınarak belirlenmiştir. Bu kapsamda "Çok yeterli =5 puan; Yeterli $=4$ puan; Orta düzeyde yeterli $=3$ puan; Yetersiz=2 puan; Çok yetersiz $=1$ puan olarak dikkate alınmıştır. 


\section{b. Gözlemci anekdotlarn}

Gözlemcilerinin süreçte aldıkları notlar (anektotlar) da betimsel analize tabi tutulmuş, söz konusu bu veriler iki kodlayıcı tarafından kelime, cümle okunup analiz edilmiştir. Bu analizi sonucunda kodlar ve temalar tanımlanmıştır. Daha sonra bu anekdotlardan elde edilen kod ve temalar gözlemcilere teyit ettirilmiştir. Çözümlenen bu verilere ilişkin kodlayıcılar arası tutarlılık (uyum) katsayısı [15 / (15+4)] x100 =,80 olarak bulunmuştur.

\section{c. Görüşme verilerinin çözümlenmesi}

Görüşme verilerine ait ses kaydı önce yazılı metine çevrilmiştir. Bu metin üzerinde betimsel analiz yapılmıştır. Bu bağlamda öğretmenin görüşleri iki kodlayıcı tarafından kelime, cümle incelenerek kod ve temalar oluşturulmuştur. Daha sonra çözümlenmiş verilerin sonuçları öğretmenle paylaşılarak kendisinin elde edilen kod ve temaları doğrulaması sağlanmıştır. Bu şekilde çözümlenen verilerin kodlayıcılar arası tutarlılık (uyum) katsayıs1 [37 / (37+7)] x $100=, 84$ olarak hesaplanmıştır.

\section{d. Doküman analizi}

Bu araştırmada doküman olarak öğretmenin 5. Sınıf Sosyal Bilgiler dersi için yaptığı ünitelendirilmiş yıllık plan incelenmiştir. Bu bölümde doküman analizinde izlenen aşamaları ve işlemlerin özellikleri açıklanmıştır.

Forster (1995)' göre doküman analizi sürecinin belli başıı beş aşaması vardır. Bunlar; dokümana ulaşma, orijinalliğini kontrol etme, dokümanları anlama, veriyi analiz etme ve veriyi kullanmadır (akt. Yıldırım ve Şimşek, 2011). Bu araştırmada doküman olarak öğretmenin hazırladığı ve okul müdürlüğü tarafından eğitim öğretim yılı başında onaylanmışünitelendirilmiş yıllık plan söz edilen sıra çerçevesinde incelenmiştir.

Ünitelendirilmiş yıllık plan, öğretim yılı süresince, öğretmenin ders vermekle yükümlü olduğu sinıflarda, program uyarınca belli ünite ve konuları hangi aylarda yaklaşık ne kadar zamanda işleneceğini gösteren, ders yılı başında okul yönetimine verilen çalışma planıdır (MEB, 2003). Öğretmenin ünitelendirilmiş yıllık planı analiz edilirken; bu planlarda bulunması gereken bölümler, her bölümün taşıması gereken özellikleri ve düzenleme ilkeleri, 
öğretme-öğrenme sürecinin öğeleri, değişkenleri ve bunlara ilişkin ilkeleri ölçütler olarak alınmıştır. Ünitelendirilmiş bir yıllık planda her öğrenme alanı / ünitesi için şu bölümler yer alır (MEB, 2003; Sönmez, 2007; Tanrıseven, 2015):

- Süre: Bu bölümde hangi ayda haftada kaç saat ders yapılacağı saptanır.

- Kazanımlar: O derste öğrencilere kazandırılması beklenen bilişsel, duyuşsal ve psiko-motor özellikler dikkate alınarak ilgili dersin öğretim programından belirlenir.

- Konular: Bu bölümde yalnızca işlenecek konuların isimlerine yer verilir.

- Yöntem ve teknikler: Bu bölümde kazanımların düzeylerine, konu alanının özelliklerine ve haftalık ders saati süresine göre kullanılması uygun olan öğretim stratejileri, yöntem ve tekniklerinin isimleri yazılmaktadır.

- Eğitim teknolojileri araç ve gereçler: Derslerin işlenişinde yardımci olacak, öğretim araç ve materyalleri, yazılı kaynaklar ve canlı kaynakların isimleri yazılır.

- Değerlendirme: Bu bölümde hangi haftalarda ne tür değerlendirmelerin yapılacağı belirtilir.

\section{Araştırmanın Geçerlik ve Güvenilirliği}

Araştırmanın konusu belirlendikten ilgili alanyazın taranmış, veri toplama araçlarının oluşturulmasında ve elde edilen verilerin analiz sürecinde Sosyal Bilgiler eğitimi alanında ve Eğitim Programları ve Öğretim alanında iki, Ölçme değerlendirme alanında bir olmak üzere toplam beş öğretim elemanından uzman yardımı alınmıştır. Ayrıca ders gözlemi sürecinde Sosyal Bilgiler öğretmenlik uygulaması dersine araştırmanın yapıldığı okula giden dördüncü sınıfta öğrenim gören iki öğretmen adayından da yardım alınarak üç gözlemcinin süreçte yer alması sağlanmıştır. Görüşmeler için hem ses kayıt cihazı hem de not alma tekniği (anekdot) birlikte kullanılmıştır. Ses kayıt cihazındaki veriler kâğıda aktarılmış böylece hem veri kaybı önlenmiş hem de veri çözümleme sürecine araştırmacı dışında uzman bir kişi daha dâhil edilerek uyum katsayısı belirlenmiştir. Gözlemci anekdotlarının ve görüşme verilerinin analizleri sonucunda ulaşılan bulgular, öğretmenle paylaşılarak katılımcı teyidi alınmıştır. Gözlemci anekdotlarında yer alan görüşler ile öğretmenle yapılan yarı yapılandırılmış görüşme verilerinin 
çözümlemelerine ilişkin kodlayıclar arası tutarlılık (uyum) katsayısı için Miles ve Huberman'ın (1994)'ın Güvenirlik = Görüş Birliği / (Görüş Birliği + Görüş Ayrılığı) x 100 formülü kullanılmıştır.

\section{Bulgular}

Bu bölümde her kazanım için ayrı ayrı gözlem formları ve gözlemci anekdotlarından elde veriler; dersin öğretmeni ile yapılan görüşme verileri ve yıllık ders planına ilişkin doküman incelemesiyle elde edilen veriler analiz edilerek her bir alt probleme ilişkin bulgular olarak düzenlenmiştir.

\section{SB-EVÖA'ında kullanılan öğretim yöntem-tekniklerine ilişkin bulgular}

ÖYT ile ilgili olarak EVÖA'ındaki dört kazanımın her biri için ayrı gözlem formları ile toplanan veriler analiz edilmiştir. Bu çerçevede öğretim yöntem ve teknikleri açısından 1. Kazanım, "Bireysel ve toplumsal ihtiyaçlar ile bu ihtiyaçların karşılanması için hizmet veren kurumları ilişkilendirir" ile ilgili olarak elde edilen bulgular Tablo 3'te verilmiştir.

Tablo 3. ÖYT açısından birinci kazanım etkinliklerine ilişkin gözlem bulguları

\begin{tabular}{ll}
\hline $\begin{array}{l}\text { Kazanımla ilgili olarak öğrencilerin; } \\
\text { (Eğitim, Sağlık Ulaşım, Güvenlik, Adalet, Haberleşme, Barınma, } \\
\text { e-devlet ve sivil toplum ile ilgili) }\end{array}$ & $\begin{array}{l}\text { Öğretmenin kullandığı } \\
\text { ÖY'leri ve düzeyleri }\end{array}$ \\
\hline Kavramların tanımını yapması & Anlatım (orta düzeyde) \\
\hline Kavramların tanımını tekrar etmesi & Örnek olay (yetersiz) \\
\hline Kavramların tanımını deftere yazması & Anlatım (yetersiz) \\
\hline Kavramlara günlük yaşamdan örnek vermesi & Rol oynama (yeterli) \\
\hline Bireysel ve toplumsal ihtiyaçların neler olduğunu açıklaması & Anlatım (yetersiz) \\
\hline Kamu kurum / sivil toplum kuruluşların isimlerini sayması & $\begin{array}{l}\text { Soru cevap (orta düzeyde } \\
\text { Keterli) }\end{array}$ \\
\hline Kamu kurum / sivil toplum kuruluşların görevlerini söylemesi & Anlatım (yetersiz) \\
\hline Kamu kurum / sivil toplum kuruluşların önemini açılaması & Soru cevap (yetersiz) \\
\hline $\begin{array}{l}\text { Kurum / sivil toplum kuruluşlarından hangi durumlarda } \\
\text { yararlanılacağına örnek vermesi }\end{array}$ & Etkinlik gözlenmedi \\
\hline $\begin{array}{l}\text { Kamu kurum/ sivil toplum kuruluşlarının web sitelerinden nasıl } \\
\text { yararlanılacağını göstermesi }\end{array}$ & $\begin{array}{l}\text { Anlatım ve soru cevap (orta } \\
\text { düzeyde) }\end{array}$ \\
\hline Diğer derslerle ilişki kurması &
\end{tabular}




\begin{tabular}{ll}
\hline Derse etkin olarak katılması & Etkinlik gözlenmedi \\
\hline Üst düzey düşünme becerilerini gerektiren sorulara cevap vermesi & Soru cevap (çok yetersiz) \\
\hline İşbirliğine dayalı grup çalışmaları yapması & Etkinlik gözlenmedi \\
\hline Düşüncelerinin ifade etmesi & $\begin{array}{l}\text { Anlatım ve soru cevap (orta } \\
\text { düzeyde) }\end{array}$ \\
\hline Günlük yazması & \\
\cline { 1 - 2 } Öz değerlendirme (neler öğrendim, vb.) yapması & \\
\cline { 1 - 2 } Ürün dosyası oluşturması & \\
\cline { 1 - 2 } Akran değerlendirme yapması & \\
\hline
\end{tabular}

Tablo 3 'te görüldüğü gibi gözlem formu ile elde edilen veriler dikkate alındığında kavramların tanımını yapmada anlatım yöntemi kullanılmış ve gözlemciler tarafından bu etkinlik orta düzeyde yeterli bulunmuştur. Kavramların tanımını tekrar ettirmede örnek olaydan yaralanmış, ancak yetersiz olarak gözlenmiştir. Yine aynı tabloda öğretmenin kazanımla ilgili öğretim etkinliklerinde ağırlıklı olarak anlatım ve soru cevap kullandığı ve bu etkinlilerin gözlemciler tarafından çoğunlukla yetersiz olarak değerlendirildiği görülmektedir. Öte yandan gözlem formunun amaçladığı, öğrencinin etkin olarak yer aldığı etkinlikler açısından bakıldığında ise, öğrenciler sadece kendilerine öğretmen tarafından verilen birkaç rolü oynama etkinliği dışında aktif olmamışlardır. Öğrenci aktifliğini sağlama yönünden ders süreci çok yetersiz bulunmuştur. Ayrıca bu kazanımla ilgili gözlenecek davranış olarak gözlem formuna tanımlanan altı davranışa ilişkin herhangi bir etkinlik de gözlenmemiştir.

Yine Tabloda görüldüğü gibi öğretmenin, ÖYT seçiminde kazanımın hedef taksonomi düzeylerini dikkate almadığı anlaşılmaktadır (Tablo 3).

2.Kazanım, "Yaşadığı yerin yönetim birimlerinin temel görevlerini açıklar" ile ilgili olarak elde edilen bulgular Tablo 4'te verilmiştir.

Tablo 4'deki ÖYT'ler açısından incelendiğinde, ikinci kazanımla ilgili etkinliklerde öğretmenin ağırlıklı olarak anlatım yöntemi kullandığı, bu yöntemin yeterlilik düzeyi de gözlenen davranışlara göre "yetersiz ile çok yetersiz" arasında değiştiği görülmektedir. Bu yöntemin dışında soru cevap ve örnek olay yöntemlerinin de kullanıldığı görülmekle birlikte yeterlilik düzeylerinin gözlemciler tarafından çok yetersiz olarak değerlendirildiği görülmektedir. 
Tablo 4. ÖYT açısından ikinci kazanım etkinliklerine ilişkin gözlem bulguları $\begin{array}{ll}\text { Kazanımla ilgili olarak öğrencilerin; } & \text { Öğretmenin kullandığı } \\ \text { (Devlet, merkezi yönetim, yerel yönetim) } & \text { ÖYT'ler ve düzeyleri }\end{array}$

\begin{tabular}{|c|c|}
\hline Kavramların tanımını yapması & Anlatım ve soru cevap (çok yetersiz) \\
\hline Kavramların tanımını tekrar etmesi & \multirow{2}{*}{ Anlatım ve soru cevap (yetersiz) } \\
\hline Kavramların tanımını deftere yazması & \\
\hline Kavramlara günlük yaşamdan örnek vermesi & \multirow{4}{*}{ Anlatım (yetersiz) } \\
\hline Yerel yönetim birimlerinin isimlerini sayması & \\
\hline Yerel yönetim birimlerinin türlerini sıralaması & \\
\hline Yerel yönetim birimlerinin görevlerini söylemesi & \\
\hline $\begin{array}{l}\text { Yerel yönetim birimlerine neden gerek duyulduğunu } \\
\text { söylemesi }\end{array}$ & Anlatım ve Örnek olay (yetersiz) \\
\hline Yerel yönetim birimlerinin önemini açılaması & Anlatım (yetersiz) \\
\hline $\begin{array}{l}\text { Yerel yönetim birimlerinden hangi durumlarda } \\
\text { yararlanılacağına örnek vermesi }\end{array}$ & Anlatım (çok yetersiz) \\
\hline $\begin{array}{l}\text { Yerel yönetim birimlerinin web sitelerinden nasıl } \\
\text { yararlanılacağını göstermesi }\end{array}$ & Anlatım (yetersiz) \\
\hline Diğer derslerle ilişki kurması & \multirow{3}{*}{ Örnek olay (çok yetersiz) } \\
\hline Örnek olaydan yararlanması & \\
\hline Derse etkin olarak katılması & \\
\hline $\begin{array}{l}\text { Üst düzey düşünme becerilerini gerektiren sorulara cevap } \\
\text { vermesi }\end{array}$ & \multirow{7}{*}{ Etkinlik gözlenmedi } \\
\hline İşbirliğine dayalı grup çalışmaları yapması & \\
\hline Düşüncelerinin ifade etmesi & \\
\hline Günlük yazması & \\
\hline Öz değerlendirme (neler öğrendim, vb.) yapması & \\
\hline Ürün dosyası oluşturması & \\
\hline Akran değerlendirme yapması & \\
\hline
\end{tabular}

Ayrıca gözlem formunun amaçladığı, öğrencinin aktif olarak yer aldığı etkinlikler açısından bakıldığında ise verilen bir örnek olay üzerinde soru cevap etkinliği gözlenmiş olmasına rağmen, bu etkinlik "çok yetersiz" düzeyde değerlendirilmiştir. Yine bu kazanım çerçevesinde gözlenmesi planlanan, öğrencilerin üst düzey düşünme becerilerini gerektiren sorulara cevap vermesi, işbirliğine dayalı grup çalışmaları yapması, düşüncelerinin ifade etmesi, günlük yazması, öz değerlendirme (neler öğrendim. vb.) yapması, ürün dosyası oluşturması, akran değerlendirme yapması şeklinde gözlem formunda yer alan yedi davranışa ilişkin herhangi bir etkinlik de gözlenmemiştir. Öğretmenin ÖYT seçiminde kazanımın hedef taksonomisi açısından düzeyini dikkate almadığı görülmektedir (Tablo 4). 
Özetle ikinci kazanımla ilgili olarak kullanılan öğretim yöntem ve Teknikleri hem kazanımın taksonomi düzeyine uygunluğu hem de öğrenci aktifliğini sağlama yönünden çok yetersiz bulunmuştur.

3.Kazanım, "Temel hakları ve bu hakları kullanmanın önemini açıklar" ile ilgili olarak elde edilen bulgular Tablo 5 'te verilmiştir:

Tablo 5. ÖYT açısından üçüncü kazanım etkinliklerine ilişkin gözlem bulguları

\begin{tabular}{|c|c|}
\hline $\begin{array}{l}\text { Kazanımla ilgili olarak öğrencilerin; } \\
\text { (Temel hak, Katılım hakkı, Düşünce özgürlüğü, Özgürlük kavram- } \\
\text { ları) }\end{array}$ & $\begin{array}{l}\text { Öğretmenin kullandığı } \\
\text { ÖYT'ler ve düzeyleri }\end{array}$ \\
\hline Kavramların tanımını yapması & $\begin{array}{l}\text { Anlatım (orta düzeyde } \\
\text { yeterli) }\end{array}$ \\
\hline Kavramların tanımın tekrar etmesi & $\begin{array}{l}\text { Anlatım ve örnek olay } \\
\text { (yetersiz) }\end{array}$ \\
\hline Kavramların tanımını deftere yazması & Anlatım (yetersiz) \\
\hline Kavramlara günlük yaşamdan örnek vermesi & \multirow{2}{*}{ Soru cevap (çok yetersiz) } \\
\hline Bireysel ve toplumsal ihtiyaçların neler olduğunu açıklaması & \\
\hline Temel haklarının isimlerini sayması & \multirow{2}{*}{ Anlatım (yetersiz) } \\
\hline Temel haklarının yasal dayanaklarını söylemesi & \\
\hline Temel haklarının ne işe yaradığını /ne fayda sağladığını söylemesi & $\begin{array}{l}\text { Anlatım ve soru cevap } \\
\text { (çok yetersiz) }\end{array}$ \\
\hline Temel haklarının önemini açıklaması & \multirow{3}{*}{ Anlatım (yetersiz) } \\
\hline Temel haklarının sağladığı faydalara örnek vermesi & \\
\hline $\begin{array}{l}\text { Temel hakları ile ilgili durumlarda web sitelerinden nası } \\
\text { yararlanılacağını göstermesi }\end{array}$ & \\
\hline Diğer derslerle ilişki kurması & Soru cevap (çok yetersiz) \\
\hline Örnek olaydan yararlanması & Örnek olay (çok yetersiz) \\
\hline Derse etkin olarak katılması & Soru cevap (yetersiz) \\
\hline Üst düzey düşünme becerilerini gerektiren sorulara cevap vermesi & \multirow{5}{*}{ Etkinlik gözlenmedi } \\
\hline İşbirliğine dayalı grup çalışmaları yapması & \\
\hline Düşüncelerini ifade etmesi & \\
\hline Günlük yazması/öz değerlendirme yapması & \\
\hline Ürün dosyası oluşturması /akran değerlendirme yapması & \\
\hline
\end{tabular}

Tablo 5'deki üçüncü kazanımla ilgili etkinliklere ilişkin gözlem sonuçları incelendiğinde öğretmenin "yetersiz ile çok yetersiz" arasında gözlenen anlatım yöntemini yoğun olarak kullandığı görülmektedir. Bu kazanımın öğretme-öğrenme sürecinde sıklık açısından ikinci sırada soru-cevap yöntemi "çok yetersiz" olarak gözlenmiştir. Sadece kavramların tanımını tekrar etmede ise örnek olaydan yararlanılmış, ancak bu yöntemin kullanım yeterliliği de "yetersiz" bulunmuştur. Yine bu kazanımla ilgili gözlenmesi 
beklenen davranışlardan öğrencilerin üst düzey düşünme becerilerini gerektiren sorulara cevap vermesi, işbirliğine dayalı grup çalışmaları yapması, düşüncelerini ifade etmesi, sürece yönelik bireysel değerlendirme vb. yedi davranışa ilişkin herhangi bir etkinlik gözlenmemiştir. Tablo 5 'te görüldüğü gibi öğretmenin bu kazanım açısından da ÖYT seçiminde kazanımın ve ilgili davranışlarının taksonomi düzeylerini dikkate alınmadığı gözlenmektedir.

4.Kazanım, "Millî egemenlik ve bağımsızlık sembollerimizden Bayrağımıza ve İstiklâl Marşına değer verir" ile ilgili olarak elde edilen bulgular Tablo 6' da verilmiştir:

Tablo 6. ÖYT açısından dördüncü kazanım etkinliklerine ilişkin gözlem bulguları

\begin{tabular}{|c|c|}
\hline $\begin{array}{l}\text { Kazanımla ilgili olarak öğrencilerin; } \\
\text { (Egemenlik, millî egemenlik, milli bağımsızlık, bayrak) }\end{array}$ & $\begin{array}{l}\text { Öğretmenin kullandığı } \\
\text { ÖYT'ler ve düzeyleri }\end{array}$ \\
\hline Kavramların tanımını yapması & Anlatım (yetersiz) \\
\hline Kavramların tanımını tekrar etmesi & \multirow{2}{*}{$\begin{array}{l}\begin{array}{l}\text { Anlatım ve soru cevap } \\
\text { (yetersiz) }\end{array} \\
\end{array}$} \\
\hline Kavramların tanımını deftere yazması & \\
\hline Kavramlara günlük yaşamdan örnek vermesi & \multirow{2}{*}{ Anlatım (yetersiz) } \\
\hline Bayrak kanununda yer alan özellikleri söylemesi & \\
\hline Bayrağın önemini açıklaması & Anlatım (orta düzeyde \\
\hline İstiklal Marşı́nın kim tarafından yazıldığını söylemesi & \multirow{3}{*}{ Anlatım (yetersiz) } \\
\hline İstiklal Marşı'nın hangi koşullarda kabul edildiğini söylemesi & \\
\hline İstiklal Marşı'nın anlamını açıklaması & \\
\hline İstiklal Marşı'nın önemini açıklaması & \multirow{2}{*}{$\begin{array}{l}\text { Anlatım } \\
\text { yeterli) }\end{array}$} \\
\hline Bayrağımız ve İstiklal Marşı' mıza nasıl davranılacağını göstermesi & \\
\hline Diğer derslerle ilişki kurması & \multirow{8}{*}{ Etkinlik gözlenmedi } \\
\hline Örnek olaydan yararlanması & \\
\hline Derse etkin olarak katılması & \\
\hline Üst düzey düşünme becerilerini gerektiren sorulara cevap vermesi & \\
\hline İşbirliğine dayalı grup çalışmaları yapması & \\
\hline Düşüncelerini ifade etmesi & \\
\hline Günlük yazması / öz değerlendirme yapması & \\
\hline Ürün dosyası oluşturması /akran değerlendirme yapması & \\
\hline
\end{tabular}

Tablo 6'deki dördüncü kazanımla ilgili etkinliklere ilişkin gözlem sonuçları incelendiğinde öğretmenin ağırlıklı olarak anlatım yöntemi kullandığı bu yöntemin yeterliliği gözlenen davranışlara göre "orta düzeyde yeterli ile çok yetersiz" arasında değiştiği görülmektedir. Anlatım yönteminin yansıra öğretmenin soru cevap yöntemini de kullandığ1 ve gözlemciler tarafından "yetersiz" düzeyde değerlendirilmiştir. Ayrıca bu kazanımla ilgili 
etkinliklerde öğrencilerde gözlenmesi beklenen "diğer derslerle ilişki kurması, örnek olaydan yararlanması, derse etkin olarak katılması, üst düzey düşünme becerilerini gerektiren sorulara cevap vermesi, işbirliğine dayalı grup çalışmaları yapması, düşüncelerinin ifade etmesi ve sürece yönelik bireysel değerlendirmeler vb. 10 davranısla ilgili etkinlikler ise gözlenememiştir.

Dördüncü kazanımla ilgili olarak da diğer üç kazanımda olduğu gibi öğretmenin kazanımın taksonomi düzeyine uygun yöntem ve teknikler seçmediği görülmektedir.

\section{SB-EVÖA'ında kullanılan öğretim materyallerine ilişkin bulgular}

Bu alt problemle ilgili olarak SB- EVÖA'daki dört kazanımla ilgili öğretmeöğrenme süreci etkinliklerinde kullanılan öğretim materyallerinin neler olduğu ve yeterlik düzeylerine ilişkin bulgular sırasıyla aşağıda yer almıştır. 1.Kazanım "Bireysel ve toplumsal ihtiyaçlar ile bu ihtiyaçların karşılanması için hizmet veren kurumları ilişkilendirir" kazanımı ile ilgili bulgular Tablo 7'de sunulmuştur.

Tablo 7. ÖM açısından birinci kazanımla ilgili etkinliklere ilişkin gözlem bulgulan

\begin{tabular}{|c|c|}
\hline $\begin{array}{l}\text { Kazanımla ilgili olarak öğrencilerin; } \\
\text { (Eğitim, Sağlık Ulaşım, Güvenlik, Adalet, Haberleşme, Barınma, e-devlet } \\
\text { ve sivil toplum ile ilgili) }\end{array}$ & $\begin{array}{l}\text { Öğretmenin } \\
\text { kullandı̆̆ı } \\
\text { ÖM'ler } \\
\text { düzeyleri }\end{array}$ \\
\hline Kavramların tanımını yapması & \multirow{3}{*}{ Ders kitabı (yetersiz) } \\
\hline Kavramların tanımını tekrar etmesi & \\
\hline Kavramların tanımını deftere yazması & \\
\hline Kavramlara günlük yaşamdan örnek vermesi & $\begin{array}{l}\text { Ders kitabi (çok } \\
\text { yetersiz) }\end{array}$ \\
\hline Bireysel ve toplumsal ihtiyaçların neler olduğunu açılaması & \multirow{2}{*}{ Ders kitab1 (yetersiz) } \\
\hline Kamu kurum / sivil toplum kuruluşların isimlerini sayması & \\
\hline Kamu kurum / sivil toplum kuruluşların görevlerini söylemesi & \multirow{2}{*}{$\begin{array}{l}\text { Ders kitabi (çok } \\
\text { yetersiz) }\end{array}$} \\
\hline Kamu kurum / sivil toplum kuruluşların önemini açılaması & \\
\hline $\begin{array}{l}\text { Kurum / sivil toplum kuruluşlarından hangi durumlarda yararlanılacağına } \\
\text { örnek vermesi }\end{array}$ & $\begin{array}{l}\text { Materyal gözlen- } \\
\text { medi }\end{array}$ \\
\hline $\begin{array}{l}\text { Kamu kurum/ sivil toplum kuruluşlarının web sitelerinden nasıl } \\
\text { yararlanılacağını göstermesi }\end{array}$ & $\begin{array}{l}\text { Akıllı tahta (video } \\
\text { izletme) (orta } \\
\text { düzeyde yeterli) }\end{array}$ \\
\hline Diğer derslerl & \\
\hline
\end{tabular}




\begin{tabular}{|c|c|}
\hline Örnek olaydan yararlanması & \multirow{7}{*}{$\begin{array}{l}\text { Materyal kullanım } \\
\text { gözlenmedi }\end{array}$} \\
\hline Derse etkin olarak katılması & \\
\hline Üst düzey düşünme becerilerini gerektiren sorulara cevap vermesi & \\
\hline İşbirliğine dayalı grup çalışmaları yapması & \\
\hline Düşüncelerini ifade etmesi & \\
\hline Günlük yazması /öz değerlendirme (neler öğrendim... vb.) yapması & \\
\hline Ürün dosyası oluşturması / akran değerlendirme yapması & \\
\hline
\end{tabular}

Tablo 7'deki ÖM'leri açısında birinci kazanımla ilgili etkinliklere ilişkin gözlem sonuçları incelendiğinde öğretme-öğrenme sürecinde öğretmenin ders kitabına bağlı kaldığı anlaşılmakta ve bu materyalin kullanımı, gözlemciler tarafindan "yetersiz ile çok yetersiz" arasında değerlendirilmiştir. Gözlem formunda bu kazanımla ilgili olarak tanımlanan "kamu kurum/ sivil toplum kuruluşlarının web sitelerinden nasıl yararlanılacağını göstermesi" davranışında öğretmen akıllı tahtayı video gösterimi amaçlı kullanmıştır. Akıllı tahtanın bu şekilde kullanımını gözlemciler orta düzeyde yeterli olarak değerlendirmiştir.

Yine Tablo 7'de görüldüğü gibi gözlenmesi amacıyla tanımlanan 20 davranıştan (ilk dokuzunda ders kitabı ve onuncusunda akıllı tahta olmak üzere toplam) ilk 10 davranışta materyal kullanımı gözlenirken, son 10 davranışta (öğrencilerin diğer derslerle ilişki kurması, örnek olaydan yararlanması, derse etkin olarak katılması, üst düzey düşünme becerilerini gerektiren sorulara cevap vermesi vb.) öğretmen materyal kullanmamıştır.

2.Kazanım, "Yaşadığı yerin yönetim birimlerinin temel görevlerini açılar" ile ilgili materyal kullanımına ilişkin bulgular Tablo 8' de verilmiştir: 
Tablo 8. ÖM açısından ikinci kazanımla ilgili etkinliklere ilişkin gözlem bulgular

\begin{tabular}{|c|c|}
\hline $\begin{array}{l}\text { Kazanımla ilgili olarak ögrencilerin; } \\
\text { (Devlet, merkezi yönetim, yerel yönetim) }\end{array}$ & $\begin{array}{l}\text { Öğretmenin kullandığı } \\
\text { ÖM'leri ve düzeyleri }\end{array}$ \\
\hline Kavramların tanımını yapması & Yazı tahtası (çok yetersiz) \\
\hline Kavramların tanımını tekrar etmesi & Yazı tahtası (yetersiz) \\
\hline Kavramların tanımını deftere yazması & $\begin{array}{l}\text { Yazı tahtası ve ders kitabı } \\
\text { (çok yetersiz) }\end{array}$ \\
\hline Kavramlara günlük yaşamdan örnek vermesi & \multirow{3}{*}{ Ders kitabı (yetersiz) } \\
\hline Yerel yönetim birimlerinin isimlerini sayması & \\
\hline Yerel yönetim birimlerinin türlerini sıralaması & \\
\hline Yerel yönetim birimlerinin görevlerini söylemesi & \multirow{5}{*}{ Ders kitabı (çok yetersiz) } \\
\hline Yerel yönetim birimlerine neden gerek duyulduğunu söylemesi & \\
\hline Yerel yönetim birimlerinin önemini açıklaması & \\
\hline $\begin{array}{l}\text { Yerel yönetim birimlerinden hangi durumlarda yararlanılacağına } \\
\text { örnek vermesi }\end{array}$ & \\
\hline $\begin{array}{l}\text { Yerel yönetim birimlerinin web sitelerinden nasıl yararlanılacağını } \\
\text { göstermesi }\end{array}$ & \\
\hline Diğer derslerle ilişki kurması & \multirow{8}{*}{$\begin{array}{l}\text { Materyal kullanımı gözlen- } \\
\text { medi }\end{array}$} \\
\hline Örnek olaydan yararlanması & \\
\hline Derse etkin olarak katılması & \\
\hline Üst düzey düşünme becerilerini gerektiren sorulara cevap vermesi & \\
\hline İşbirliğine dayalı grup çalışmaları yapması & \\
\hline Düşüncelerinin ifade etmesi / Günlük yazması & \\
\hline Öz değerlendirme (neler öğrendim, vb.) yapması & \\
\hline Ürün dosyası oluşturması / Akran değerlendirme yapması & \\
\hline
\end{tabular}

İkinci kazanım olan "Yaşadığı yerin yönetim birimlerinin temel görevlerini açıklar" ile ilgili materyal kullanımına ilişkin Tablo 8'deki gözlem sonuçları dikkate alındığında, öğretmenin materyal olarak çoğunlukla ders kitabı kullandığı anlaşılmaktadır. Ders kitabının kullanımı da gözlemciler tarafından "yetersiz ile çok yeteriz" arasında gözlenmiştir. Bunun dışında öğretmenin "kazanımla ilgili kavramların tanımını yaptırma, bu tanımları öğrencilere tekrar ettirme ve deftere yazdırma etkinliklerinde yazı tahtasından yararlandığı gözlenmektedir. Ancak gözlemcilere göre yazı tahtasının bu amaçla kullanımları "yetersiz ile çok yetersiz" arasında değerlendirilmiştir. Öte yandan ilk kazanımda olduğu gibi bu kazanımda da gözlem formunda tanımlanan 20 davranıştan ilk 10 davranışta materyal kullanımı gözlenirken son 10 davranışta öğretmenin materyal kullanmadığı görülmektedir. 
3.Kazanım, "Temel hakları ve bu hakları kullanmanın önemini açıklar" ile ilgili materyal kullanımına ilişkin bulgular Tablo 9'da verilmiştir:

Tablo 9. ÖM açısından üçüncü kazanımla ilgili etkinliklere ilişkin bulgular

\begin{tabular}{|c|c|}
\hline $\begin{array}{l}\text { Kazanımla ilgili olarak öğrencilerin; } \\
\text { (Temel hak, Katılım hakkı, Düşünce özgürlüŭüü, Özgürlük kavram- } \\
\text { ları) }\end{array}$ & $\begin{array}{l}\text { Öğretmenin kullandığı } \\
\text { ÖM'leri ve düzeyleri }\end{array}$ \\
\hline Kavramların tanımını yapması & Ders kitabı (orta düzeyde) \\
\hline Kavramların tanımını tekrar etmesi & \multirow[t]{2}{*}{ Ders kitab1 (yetersiz) } \\
\hline Kavramların tanımını deftere yazması & \\
\hline Kavramlara günlük yaşamdan örnek vermesi & Ders kitabı (çok yetersiz) \\
\hline Bireysel ve toplumsal ihtiyaçların neler olduğunu açılaması & \multirow{3}{*}{ Ders kitab1 (yetersiz) } \\
\hline Temel haklarının isimlerini sayması & \\
\hline Temel haklarının yasal dayanaklarını söylemesi & \\
\hline Temel haklarının ne işe yaradığını /ne fayda sağladığını söylemesi & \multirow{6}{*}{ Ders kitabı (çok yetersiz) } \\
\hline Temel haklarının önemini açıklaması & \\
\hline Temel haklarının sağladığı faydalara örnek vermesi & \\
\hline $\begin{array}{l}\text { Temel hakları ile ilgili durumlarda web sitelerinden nasıl } \\
\text { yararlanılacağını göstermesi }\end{array}$ & \\
\hline Diğer derslerle ilişki kurması & \\
\hline Örnek olaydan yararlanması & \\
\hline Derse etkin olarak katılması & Yazı tahtası (yetersiz) \\
\hline Üst düzey düşünme becerilerini gerektiren sorulara cevap vermesi & \multirow{7}{*}{$\begin{array}{l}\text { Materyal } \\
\text { gözlenmedi }\end{array}$} \\
\hline Işbirliğine dayalı grup çalışmaları yapması & \\
\hline Düşüncelerini ifade etmesi & \\
\hline Günlük yazması / & \\
\hline Öz değerlendirme yapması & \\
\hline Ürün dosyası oluşturması & \\
\hline Akran değerlendirme yapması & \\
\hline
\end{tabular}

Tablo 9' daki bulgular incelendiğinde “Temel hakları ve bu hakları kullanmanın önemini açılar" kazanımı etkinlerinde tanımlanan toplam 21 davranışın ilk 14'ünde materyal kullanımı gözlenirken son yedisinde gözlenememiştir. Öğretmenin ilk 14 davranışla ilgili etkinliklerin 13'ünde kullandığı materyal ise sadece ders kitabı olduğu görülmektedir. Ders kitabının bu kullanımına ilişkin yeterlik düzeyleri gözlemci değerlendirmelerinde "orta düzeyde yeterli ile çok yetersiz" arasında değişmektedir.

4.Kazanım: "Millî egemenlik ve bağımsızlık sembollerimizden Bayrağımıza ve İstiklâl Marşına değer verir" ile ilgili materyal kullanımına ilişkin bulgular Tablo 10'da verilmiştir: 
Tablo 10. ÖM açısından dördüncü kazanımla ilgili etkinliklere ilişkin gözlem bulgulan

\begin{tabular}{|c|c|}
\hline $\begin{array}{l}\text { Kazanımla ilgili olarak öğrencilerin; } \\
\text { (Egemenlik, millî egemenlik, milli bağımsızlık, bayrak) }\end{array}$ & $\begin{array}{l}\text { Öğretmenin kullandığı } \\
\text { ÖM'leri ve düzeyleri }\end{array}$ \\
\hline Kavramların tanımını yapması & \multirow{3}{*}{$\begin{array}{l}\text { Ders kitabı (orta düzeyde } \\
\text { yeterli) }\end{array}$} \\
\hline Kavramların tanımını tekrar etmesi & \\
\hline Kavramların tanımını deftere yazması & \\
\hline Kavramlara günlük yaşamdan örnek vermesi & Ders kitabı (çok yetersiz) \\
\hline Bayrak kanununda yer alan özellikleri söylemesi & \multirow{3}{*}{$\begin{array}{l}\text { Ders kitabı (yetersiz) } \\
\begin{array}{l}\text { Ders kitabı (orta düzeyde } \\
\text { yeterli) }\end{array}\end{array}$} \\
\hline Bayrağın önemini açklaması & \\
\hline İstiklal Marşı'nın kim tarafından yazıldığını söylemesi & \\
\hline İstiklal Marşı'nın hangi koşullarda kabul edildiğini söylemesi & \multirow{4}{*}{$\begin{array}{l}\text { Ders kitabı (yetersiz) } \\
\begin{array}{l}\text { Ders kitabı (orta düzeyde } \\
\text { yeterli) }\end{array}\end{array}$} \\
\hline İstiklal Marşı'nın anlamını açıklaması & \\
\hline İstiklal Marşı'nın önemini açıklaması & \\
\hline Bayrağımız ve İstiklal Marşı' mıza nasıl davranılacağını göstermesi & \\
\hline Diğer derslerle ilişki kurması & \multirow{10}{*}{$\begin{array}{l}\text { Materyal kullanımı gözlen- } \\
\text { medi }\end{array}$} \\
\hline Örnek olaydan yararlanması & \\
\hline Derse etkin olarak katılması & \\
\hline Üst düzey düşünme becerilerini gerektiren sorulara cevap vermesi & \\
\hline İşbirliğine dayalı grup çalışmaları yapması & \\
\hline Düşüncelerini ifade etmesi & \\
\hline Günlük yazması & \\
\hline Öz değerlendirme (neler öğrendim, vb.) yapması & \\
\hline Ürün dosyası oluşturması & \\
\hline Akran değerlendirme yapması & \\
\hline
\end{tabular}

Tablo 10'da "Millî egemenlik ve bağımsızlık sembollerimizden Bayrağımıza ve İstiklâl Marşına değer verir" kazanımı ile ilgili etkinliklerde öğretmen tarafından kullanılan materyallere ilişkin bulgular dikkate alındığında gözlem formunda tanımlanan 21 davranışın ilk 11'inde ders kitabı kullandığ görülmektedir. Bu 11 davranışla ilgili etkinliklerde ders kitabı kullanımı ile ilgili olarak gözlemcilerin değerlendirmeleri "orta düzeyde yeterli ile çok yetersiz" arasında değişmektedir. Geri kalan diğer 10 davranışla ilgili olarak herhangi bir materyal kullanımına rastlanmamıştır.

\section{SB-EVÖA'ı etkinliklerine yönelik gözlemci anekdotlarndan elde edilen bul- gular}

Gözlemcilerin, gözlem formu dışında altı haftalık gözlem süresince derslerin işlenişi ile ilgili olarak tuttukları kendi anektotlardan elde edilen tema ve kodlar Tablo 11'de verilmiştir: 
Tablo 11'e göre gözlemci anekdotlarından öğretme-öğrenme süreçlerinin iki temel boyutu olan ders öncesi ve ders süreci temaları elde edilmiştir. Ders süreci teması da kendi içinde öğretim yöntem ve teknikleri, öğretim materyali, zaman yönetimi ve iletişim-etkileşim alt temaları elde edilmiştir.

Tablo 11. Gözlemci anekdotlarndan elde edilen bulgular

\begin{tabular}{l|l}
\hline A. Ders öncesi & B3. Öğretmenin zaman yönetimi \\
\hline Öğretmenin derse hazırlıklı gelmemesi & Ders süresini yönetememe \\
\hline Öğrenci konuları araştırıp not alarak gelmesi & Derse geç gelme (20 dk) \\
\hline B. Ders süreci & $\begin{array}{l}\text { Bir kavramla bir ders saatini bitirme (Gereksiz } \\
\text { ayrıntılara girme) }\end{array}$ \\
\hline B1.Öğretim yöntem ve teknikleri & Konuları zamanında yetiştirememe \\
\hline Düz anlatım kullanma & Kendi hayatını öne çıkarma \\
\hline Soru cevap kullanma & B4. İletişim -etkileşim \\
\hline Konuyu kitaptan tekrar yazdırma & Öğrencinin pasif kalması \\
\hline Bir konu anlaşılmadan diğerine geçme & Öğrencinin anlamadı̆̆ını soramaması \\
\hline B2.Öğretim Materyali & Öğretmenin kaba ifadeler kullanması \\
\hline Ders kitabı (Konu özetli soru bankası) & Öğretmenin gereksiz ve ani tepkiler verme \\
\hline Yazı tahtası & Öğretmenin konu dışına çok çıkma \\
\hline Akıllı tahta (çok az) & \\
\hline
\end{tabular}

Ders öncesi temasında "öğretmenin derse gelmeden önce hazırlık yapmadığı" gözlemcilerde yaygın bir kanaat oluştururken, öğrencilerin konuları önceden (özellikle internetten) araştırıp not alarak geldikleri görülmüştür. Öğretim yöntem ve teknikleri alt teması altında ise birinci alt problemde yer alan dört kazanımda da gözlendiği gibi öğretmenin düz anlatım ve soru cevap uygulamalarını çok yoğun olarak kullandığı gözlemci anekdotlarında da vurgulanmaktır. Ders öncesi temasında da söz edildiği gibi derse konuları araştırıp not alarak gelen öğrencilere öğretmenin konuyu "özetli soru bankası kitabından okuyarak tekrar yazdırdığı" ve "öğrencilerin bir konuyu tam olarak anlayamadan öğretmen tarafından başka bir konuya geçildiği" gözlemci anekdotlarında yer almaktadır.

Öğretim materyali alt teması altında da ikinci alt problemde yer alan dört kazanımla ilgili bulgularda da ulaşıldığı gibi öğretmenin tüm derslerinin neredeyse tamamında sadece "konu özetli soru bankası ders kitabı ve yazı tahtası" kullandığı; çok nadiren de akıllı tahtadan yararlandığı tespit edilmiştir. Zaman yöntemi alt temasında ise gözlemcilerin anekdotlarında öğretmenin ders süresini çok iyi yönetemediği, bazı derslere yaklaşık 20 dakika geç kaldığı, gereksiz ayrıntılarla bir ders saatinin tamamını harcadığı, 
ders sürecinde konu dışına çok çıarak ilgisiz konularla (özellikle kendi hayatıyla) zaman kaybetmekte ve konuları zamanında yetiştiremediği belirtilmektedir.

İletişim-etkileşim alt temasında öğrencilerin ders sürecinde pasif olması, anlamadığı yerleri soramaması, öğretmenin kullandığı dilin kaba oluşu; gereksiz şekilde ani tepkiler vermesi ve çok sık bir şekilde konu dışına çıarak hem dikkatleri dağıtması hem de süreyi etkili kullanamaması gibi bulgular gözlemcilerin aldığı notlar arasında dikkat çekmektedir. Gözlemci anekdotlarından elde edilen görüşlerden bazıları doğrudan alıntı yapılarak aşağıda verilmiştir:

“Öğretmen dersi işlerken sadece konu özetli soru bankası kullanıyor (Gözlemci 2) “Öğrenciler dersten önce konuyu araştırıp, defterlerine notları alıyorlar. Öğretmen aynı konuyu kitaptan bakarak tekrardan yazdırıyor" (Gözlemci 1).

"Öğretmen, derste öğrenciler tam olarak o konuyu anlamadan başka bir konuya geçiyor. Öğrenciler konuyu anlamayınca hoca sinirleniyor ve sinirini biz orada olduğumuz için bastırmaya çalışıyor" (Gözlemci 3)

"Öğretmen derse tam hazırlk yaparak gelmiyor. Derste sadece klasik teknikler olan düz anlatım ve soru cevap tekniklerini kullanıyor. Dersin bitiş sürelerini bilmediğ $i$ için derste zaman yönetimi konusunda sıkıntı yaşıyor" (Gözlemci1)

"Derse geç giriyor ve ders konuları bu yüzden yetişmiyor. Öğretim tekniği olarak sadece düz anlatım ve soru cevap kullanıyor" (Gözlemci 3)

\section{SB-EVÖA ile ilgili öğretmenin yıllık plandan elde edilen bulgular}

Bu alt problem kapsamında da öğretmenin 2018-2019 eğitim öğretim yillık planı incelendiğinde Şekil 1.de verilen ana bölümlerden oluştuğu görülmektedir.

Şekil 1'de görüldüğü gibi 2018-2019 eğitim öğretim yılı Sosyal Bilgiler ünitelendirilmiş yıllık planının başında okulun adı, hangi yıla ait olduğu ve dersin adı yer almaktadır. Alt satırlarında bu yıllık planın genel ağ üzerinden Milli Eğitim Bakanlığının hangi adresine yüklenmesi gerektiği bilgisi ve öğrenme alanı bölümü yer almaktadır. Söz konusu yıllık plan "hafta, ders saati, konu, kazanımlar, Atatürkçülükle ilgili konular, değerler eğitimi, kullanılan eğitim teknolojileri, araç ve gereçleri, öğrenme-öğretme yöntem ve teknikleri ile belirli gün ve haftalar olmak üzere toplam on sütundan oluşan bölümlere ayrılmıştır. 


\begin{tabular}{l}
$\begin{array}{l}\text {... Ortaokulu 2018-2019 Eğitim Öğretim Yllı 5. Sınıf Sosyal Bilgiler Dersi Ünitelendirilmiş Ylllık } \\
\text { Planı }\end{array}$ \\
$\begin{array}{l}\text { Bu yıllık plan http://e-mufredat.meb.gov.tr genel ağ adresindeki “Yllık Plan modülüne de } \\
\text { haftalık ana şablon olarak yüklenecektir. }\end{array}$ \\
\hline \multicolumn{2}{|l|}{ Öğrenme alanı...................... } \\
\hline
\end{tabular}

Şekil 1. 2018-2019 Ĕ̆gitim öğretim yılı Sosyal Bilgiler dersi ünitelendirilmiş yıllık planı

Alt problem doğrultusunda 2018-2019 Eğitim Öğretim Sosyal Bilgiler yıllık planında EVÖA'ıyla ilgili bölüm ele alındığında gözlenen konu başlıkları ve içerikleri Tablo 12'de verilmiştir.

EVÖA'nındaki yıllık plan bölümleri ve içeriklerinin yer aldığı Tablo 12'i incelendiğinde söz konusu öğrenme alanının Nisan ayının ikinci haftası ile Mayıs ayının ilk haftası arasında, her kazanım için 3'er saat olmak üzere toplam dört hafta ve 12 saat olarak planlandığı görülmektedir. Ancak gözlem sürecinde bu zaman planlaması, öğretmenin zaman yönetimindeki izlediği yaklaşım nedeniyle 1 ve 2 . kazanımlar için 6'şar saat, 3 ve 4 . kazanımlar için 3'er saat olmak üzere toplam 18 saat ve altı haftaya sarkmış olarak gerçekleşmiştir.

EVÖA'ında “Konu, Kazanımlar Atatürkçülükle ilgili konular, Değerler eğitimi" başlıkları Millî Eğitim Bakanlığının 2018 5. Sınıf Sosyal Bilgiler ögretim programında yer alan içerik ve başlıklarla birebir aynı olarak düzenlendiği görülmektedir.

Kullanılan eğitim teknolojileri, araç ve gereçleri başlığı altında "Akıllı Tahta EBA" ifadesi yer almaktadır. Ancak gözlem sürecinde öğretmen bu uygulamayı çok nadir düzeyde kullanmıştır. Yıllık planda yer alan diğer öğrenme alanlarına göz atıldığında hepsinde de aynı ifadenin yer aldığ görülmektedir. Dolayısıyla bu ifade sadece EVÖA'na ait değildir. Öte yandan, öğretmenin ders sürecinde çok yoğun olarak kullandığı ders kitabı ve yazı tahtasına yıllık planın bu bölümünde yer verilmemiştir.

Yine bölümde alanyazında Sosyal Bilgiler öğretiminde kullanılabileceği önerilen çok çeşitli sayıda materyallerden (anlam çözümleme /karşılaştırma 
tabloları, bilmece, bulmaca çalışma yaprağı kavram haritaları internet kullanımı, gazete ve dergilerden yararlanma, bilgisayar ve internet teknolojileri, kaynak kişi, iki ve üç boyutlu görseller vb.) söz edilirken bu araştırma sürecinde hiçbirinin kullanımına rastlanmamıştır.

Tablo 12. Yallık planda SB-EVÖA'na ilişkin konu başlıklan ve içerikleri

\begin{tabular}{|c|c|}
\hline Ay ve hafta, & Nisan'ın 2.hafta ile Mayıs'ın ilk haftası \\
\hline Ders saati & Her kazanım için 3'er saat (3x4= toplam 12 saat) \\
\hline \multirow[t]{4}{*}{ Konu } & Halka hizmet veren kurumlar \\
\hline & Yaşadığım yerin yönetimi \\
\hline & Temel haklarımızı öğrenelim \\
\hline & Bayrağımız ve İstiklal Marşı \\
\hline \multirow[t]{4}{*}{ Kazanımlar } & $\begin{array}{l}\text { 1. Bireysel ve toplumsal ihtiyaçlar ile bu ihtiyaçların karşılanması için } \\
\text { hizmet veren kurumları ilişkilendirir }\end{array}$ \\
\hline & 2. Yaşadığı yerin yönetim birimlerinin temel görevlerini açıklar. \\
\hline & 3. Temel hakları ve bu hakları kullanmanın önemini açıklar. \\
\hline & $\begin{array}{l}\text { 4. Millî egemenlik ve bağımsızlık sembollerimizden Bayrağımıza ve } \\
\text { İstiklâl Marşına değer verir }\end{array}$ \\
\hline Atatürkçülükle ilgili konular, & $\begin{array}{l}\text { 4. Kazanımda "Atatürk'ün bağımsızlığa verdiği önem vurgulanacak- } \\
\text { tır." }\end{array}$ \\
\hline \multirow[t]{3}{*}{ Değerler eğitimi } & $\begin{array}{l}\text { 1.Kazanım için: Özgürlük, Bağımsızlık, Çalışkanlık, Duyarlılık, Saygı, } \\
\text { Sevgi, Sorumluluk, Vatanseverlik, Yardımseverlik; } \\
\text { 2.Kazanım için: çalışkanlık, duyarlılık, sorumluluk, }\end{array}$ \\
\hline & $\begin{array}{l}\text { 3.Kazanım için: Dayanışma, Sorumluluk, Duyarlılık, Eşitlik, } \\
\text { Özgürlük, Yardımseverlik; Saygı, Sevgi, }\end{array}$ \\
\hline & $\begin{array}{l}\text { 4. Kazanım için: Bağımsızlık, Vatanseverlik, Duyarlılık, Özgürlük, } \\
\text { Sorumluluk, }\end{array}$ \\
\hline $\begin{array}{l}\text { Kullanulan eğitim teknolojileri, } \\
\text { araç ve gereçleri, }\end{array}$ & Akıllı tahta EBA \\
\hline $\begin{array}{l}\text { Öğrenme-öğretme yöntem ve } \\
\text { teknikleri }\end{array}$ & $\begin{array}{l}\text { Anlatım, soru-cevap, gezi-gözlem tartışma (panel, münazara, forum } \\
\text { vb) örnek olay, beyin fırtınası, bireysel çalışma, grupla çalışma, prob- } \\
\text { lem çözme, kaynak kişilerden yararlanma, gösteri, drama ve rol } \\
\text { yapma, altı şapka teknikleri }\end{array}$ \\
\hline Belirli gün ve haftalar & Kut'ül Amare Zaferi \\
\hline
\end{tabular}

EVÖA'ında öğrenme-öğretme yöntem ve teknikleri başlığı altında "anlatım, soru-cevap, gezi-gözlem tartışma (panel, münazara, forum vb) örnek olay, beyin fırtınası, bireysel çalışma, grupla çalışma, problem çözme, kaynak kişilerden yararlanma, gösteri, drama ve rol yapma, altı şapka teknikleri" listelenmiştir. Ancak gözlem sürecinde öğretmenin çok yoğun şekilde anlatım ve soru cevap yöntemi kullandığı, az da olsa (kitapta yer alan) örnek olaylardan yararlandığı, çok nadir olarak da öğrencilere rol vererek rol oynama yaptırdığı görülmüştür. Ancak bu yöntemlerin etkililikleri gözlemciler 
tarafından genel olarak "yetersiz ya da çok yetersiz" bulunsa da öğretmenin anlatım, soru cevap, örnek olay, rol oynama dışındaki yöntem ve teknikleri hiç kullanmadığı gözlenmiştir. Ayrıca söz konusu öğrenme alanında öğretim yöntem ve teknikleri, planın ilgili sütununda liste şeklinde yazılmış olup konuların ve kazanım düzeylerinin dikkate alınmadığı çok açık bir şekilde görülmektedir. Başka bir ifade ile öğretmen tarafından yöntem teknik isimleri konunun ve kazanımların özellikleri dikkate alınmadan yazılmış olduğu anlaşılmaktadır.

Öte yandan yıllık planda yer alan diğer öğrenme alanlarına da bakıldığında ÖYT başlıkları altında hep "aynı liste içeriğinin” kopyalanıp yapıştırıldığı görülmektedir. Dolaysıyla EVÖA'ı için yazılan ÖYT isimlerinin sadece bu öğrenme alanına özgü olmadığı görülmektedir. Alınyazında hem Sosyal Bilgiler öğretiminde hem de genel olarak öğretme-öğrenme sürecinde öğrencinin daha etkin olabileceği çok sayıda yöntem ve teknik çeşitliliği varken ne yıllık planın genelinde ne de EVÖA'ı boyutunda söz konusu bu çeşitlilik gözlenmemiştir.

\section{SB-EVÖA ile ilgili olarak öğretmenin görüşlerinden elde edilen bulgular}

Bu alt problem kapsamında dersin öğretmeni ile yapılan görüşme kaydı analiz edilerek elde edilen tema ve kodlar Tablo 13' de verilmiştir:

EVÖA'ındaki öğretme-öğrenme etkinlikleri doğrultusunda dersin öğretmeni ile yapılan görüşme verilerinin analizi sonucunda Tablo 13'de görüldüğü gibi "programın genel özellikleri, öğrenci nitelikleri ve dersin işlenişi" olmak üzere üç tema orta çıkmıştır.

Programın genel özellikleri teması altında öğretmen, SBDÖP'nın olumlu ve olumsuz yönlerini belirterek, geliştirilmesi düşünülen programlarda dikkate alınması için öneriler sunmuştur. Bu kapsamda öğretmen, programın olumlu özellikleri olarak; içeriğinin basit, görsel unsurlarla desteklenmesi ve bilgilerin somu şekilde sunumu olarak belirtirken; ders içeriğinin bir tarih, bir coğrafya, bir vatandaşlık konusu şeklinde sıralanmasını, bazı ünitelerin öğrencilerin sınıf düzeyinin üstünde olmasını, içerikteki bilgilerim öğrencilerin günlük yaşamları ile ilişkili olmadığı yönünde eleştiriler dile getirmiştir. 
Tablo 13. EVÖA'ı ile ilgili olarak öğretmenin görüşlerinden elde edilen bulgular

\begin{tabular}{|c|c|}
\hline 1. Genel olarak programın & 3. Ders işlenişi \\
\hline A. Olumlu yönleri & Sadece düz anlatım kullanması \\
\hline İçeriklerin somutlaştırılmış olması & Öğrenci alışkanlıkları okuma-yazma olması \\
\hline Görsel unsurlarla desteklenmesi & Düz anlatıma dayalı somutlaştırma yapması \\
\hline Program çok iyi ve basit olması & Puzzle kullanması (Haritada illeri yerleştirme) \\
\hline B. Olumsuz yönleri & $\begin{array}{l}\text { Farklı yöntemlerin işe yaramayacağının düşün- } \\
\text { mesi }\end{array}$ \\
\hline İlkçağ uygarlıkları ünitesinin erken olması & Ünite özetlerini fotokopi olarak vermesi \\
\hline $\begin{array}{l}\text { İçeriğin tarih, coğrafya ve vatandaşlık şeklinde } \\
\text { sıralanması }\end{array}$ & Şarkı kullanması \\
\hline $\begin{array}{l}\text { Okulumdaki öğrencilerin seviyesine göre uygun } \\
\text { değil }\end{array}$ & $\begin{array}{l}\text { Öğrencilere isim vermesi (konuyla ilgili kavram, } \\
\text { yer vb.) }\end{array}$ \\
\hline Program içeriği çok yüklü ve saat yetersiz & Şemalaştırma etkinlikleri yapması \\
\hline Bilgiler öğrencilerimin günlük yaşamı desteklemiyor & Okulun materyal yetersizliği olması \\
\hline Programların çok sık değişmesi & Benzetmeler kullanması \\
\hline C. Program hazırlamada öneriler & Ödev uygulaması olmaması \\
\hline Okulun bulunduğu çevrenin dikkate alınması & Yapılan her şey okulda kalması \\
\hline Öğrenci özelliklerinin dikkate alınması & EBA, akıllı tahta, video kullanması \\
\hline Aile özelliklerinin dikkate alınması & $\begin{array}{l}\text { Yarışlarda amacın öğrenmek değil, kazanmak ol- } \\
\text { ması }\end{array}$ \\
\hline Sosyo ekonomik özellikler dikkate alınması & $\begin{array}{l}\text { Farklı yöntemlerin işe yaramayacağını düşün- } \\
\text { mesi }\end{array}$ \\
\hline $\begin{array}{l}\text { İçeriğin tarih, coğrafya ve vatandaşlık olarak ayril- } \\
\text { ması }\end{array}$ & $\begin{array}{l}\begin{array}{l}\text { Sınava yönelik özetli soru bankası kitabı } \\
\text { kullanması }\end{array} \\
\end{array}$ \\
\hline Ders saatlerinin artırlması & \\
\hline 2. Öğrenci nitelikleri & \\
\hline Öğrenci seviyesinin düşük olması & \\
\hline Sınav odaklı düşünmesi & \\
\hline Sadece ezberleyerek öğrenmesi & \\
\hline Çoktan seçmeli test mantı̆̆ında olması & \\
\hline Tartışma, yorum yapamaması & \\
\hline Farklı açlardan düşünememesi & \\
\hline Hayata geçirememe (Illişkilendirme, örneklendirme) & \\
\hline Okuma ve yazma ağırlıklı öğrenme isteğinde olması & \\
\hline Öğrencinin almaya açk olmaması & \\
\hline Az bilgiyle yetinme isteği & \\
\hline Derse katılım istekleri çok düşük olması & \\
\hline Öğrenciye öğrenmede ailenin destek sağlamaması & \\
\hline
\end{tabular}

Bunun yanında öğretmen, yeni programların hazırlanmasında, ders içeriğinin temel disiplinlere ayrılması gerektiğini; okul, öğrenci, aile vb. temel öğelerin özelliklerinin de dikkate alınması gerektiği vurgulamıştır.Öğrenci nitelikleri temasında öğretmen; öğrencilerin nitelik ve beklentilerinin düşük olduğunu, sınav odaklı ve test mantığında düşündüklerini, anlamak yerine 
ezberlemeyi tercih ettiklerini, bilgileri günlük yaşama geçiremediklerini, farklı düşünme, tartışma, yorumlama, örneklendirme, ilişkilendirme vb. zihinsel süreç etkinliklerinde iyi olmadıklarını, az bilgiyle yetinme çabası içinde olduklarını ifade etmektir.

Ders işlenişi teması altında ise öğretmen, deneyimleri sonucunda farklı yöntemler kullanmanın işe yaramayacağının düşündüğünü ve öğrencilerin temel öğrenme alışkanlarının okuma ve yazma olması nedeniyle, derslerinde düz anlatım yöntemini kullandığını belirtmektir. Derslerinde okulunda materyal yetersizliği olmasına, rağmen düz anlatıma dayalı somutlaştırma, şarkı, şema, benzetme, puzzle kullanma, özet fotokopileri verme, EBA ve akıllı tahtadan yararlandığını, ders kitabı yerine de sinavlara yönelik konu özetli soru bankası kullandığını söylemektedir. Ödev uygulamasının yasak olması nedeniyle sınıf içi öğrenme etkinliklerinin sınıfta kaldığını, günlük hayata yansımadığından söz etmektedir. Bu tema ve kodların elde edildiği ders öğretmeninin görüşlerini yansıtan bazı ifadeler doğrundan alıntı yapılarak aşağıda verilmiştir:

“...ilkçağ uygarlikları konusu çocuklar tarafindan sadece ezberlenebiliyor, daha akılda kahıı etkinlikler yapamıyoruz, isimleri telaffuz etmekte zorlanıyorlar, yüzyıl olarak düşünemiyorlar ve uygarlkklarm nerede kurulduğunu algılamakta zorlanıyorlar. Öğrencilerin seviyesine göre erken..."

"Yeni programların öğrenci merkezli, öğrenci ihtiyaçlarmı karşılama vb. özelikleri konusunda ikilemde kalıyorum, programı kötülemek de istemiyorum, ama okulun bulunduğu çevrenin gereği öğrenciler donanıml gelmediği için bu programdaki kazanımların çok azını alabiliyor."

"Etkin vatandaşlık hayatla iç içe ... ama çocukların aklında ailede büyüklerinden duydukları kalıyor... örneğin, gündemde seçim olduğu için biliyorlar... Valinin, kaymakamin seçimle işbaşına geldiğini düşünüyorlar. X kişisiburadan aday olmuş, şuradan aday olmuş, duyuyorlar... şimdi ilin en üst düzey yönetici kim diye sorsanı "muhtar" derler. Mahallesinde, ailesinde en çok onu konuşuyor, onunla haşir neşir oluyor, TV'den onu duyuyor, öyle düşünüyorlar..."

"Öğrencilerin ve ailelerinin beklentileri çok düşük... günlük hayatta kullanılacak "çok az bir bilgi yeter" diyorlar. Bir ilçede çalışırken bu programın aynısını orada da işledim. Gayet sorumlu veliler olduğu için program çok güzel aktı gerçekten. Çocuklarm seviyesine uygun, çocuklar soruyu çözer, etkinlikleri yapard, yapamadıkları soruları bana getirirlerdi. Ya da kaymakam mı daha yetkili ilçe milli eğitim 
müdürü mü? Ayırt edebiliyordu. Çünkü onları okullarında görebiliyorlardı ve de küçük bir yer olduğu için bunları sorguluyorlardı..."

“Öğrenci dersteki konuları hayatında kullanabileceğini düşünmüyor, sadece ders konusu olarak görüyor. Vali ve belediye başkanını yardıma muhtaç insanlara yardım eden kişi olarak görü̈yor... onlardan yardım aldiklarn için... İşine geldiğini öğrenecek, istediği kadar öğrenecek, ihtiyacı olanı merak ediyor... hedefleri çok yüksek değil..."

“...Program ashnda güzel... basit... burada da öğrenci biraz fazla boş. Ezberden uzaklaşalım dedikçe biraz boş bırakmış oluyoruz. Ödev yok mesela... sinıfta somutlaştırirsin mesela... ama onunla ilgili bir ödev hazırlamasinn istersen daha kalıcı olabilir... ödev yok. Bazı öğrenciler kendi isteklerine göre önceden hazırlanıp geliyor..."

“...Drama etkinliklerinden çok etkilendiklerini düşündüm... dersler sıkıcı... Derste eğlence istiyorlar. Kolay sunsan bile öğrenciler daha kolay istiyor... üç dört öğrencinin dışında kalıcı öğrenme sağlanamıyor..."

"Çocuklarm derslerini günlük olarak tekrar etmeleri gerektiğini anlatamıyorum... Testlerle, örneklerle desteklemek gerektiğini söylüyorum, ama ders derste kalıyor, yazllıya bir gün kala çalışıllıyor."

"Sinavları çok yakından takip eden bir Sosyal Bilgiler öğretmeni var, soruları birebir çıkıyor, onun soru bankasını kullanıyorum. 6-7 öğrencim bilinçli olarak aldı, geri kalanlar sorularla ilgilenemedi. Sürekli uyarn bana çözmedikleri sorular getirmelerini söylesem de getiren yok... Ders kitabı takip etmiyorum açıkçası Eba'yı kullanyyorum, orada görseller ve videolar var, ders kitapları ile aynı... Simfta yeri gelince video açıyorum, Eba'daki slaytlarm bulunduğu videoyu açıyorum..."

Özet olarak bu alt problem kapsamında dersin öğretmeni ile yapılan görüşmelerden elde edilen bulgular çerçevesinde; öğrencilerin seviyelerin düşük olduğunu, öğrenmek ve anlamak yerine ezberlemeyi tercih ettiklerini, sınav odaklı çalıştıklarını söyleyen öğretmen, diğer taraftan ise öğrencilerin materyal ve oyun ihtiyaçlarını fark ettiğini, materyal kullanıldığında ulaşılabilecek sonucun çok olumlu olacağının tespitini yapmaktadır. Ancak buna rağmen öğretmen, öğretme yöntem- teknikleri ve materyal kullanmada açısından alışılagelmiş klasik ve tek düze anlayışa dair uygulamaları devam ettirme çelişkisini yaşamaktadır.

\section{Tartışma ve Sonuç}

5. Sınıf SB-EVÖA alanı ile ilgili öğretme-öğrenme süreci etkinliklerine ilişkin 
ders gözlemleri, görüşmeci anektotları, yıllık plan ve öğretmenle görüşme yoluyla elde edilen verilerden ulaşılan sonuçlar bu bölümde irdelenmiştir.

Buna göre öğretme-öğrenme süreci, öğretme yöntem-teknikleri açısından ele alındığında; gözlem formundaki değerlendirmelere ve gözlemci anektotlarına göre öğretmenin ağırlıklı olarak düz anlatım ve soru cevap yöntemi kullandığı, bunların yanı sira az da olsa kitaptaki örnek olaylardan yararlandığı, öğrencilere oturdukları yerde kendilerine verilen rolle sınırlı olmak üzere rol oynama kullandığı ve öğrenci aktifliğini sağlamadığı sonucuna ulaşılmıştır. Bu sonuçlar (Aykaç, 2007; Polat 2006)'ın Sosyal Bilgiler öğretiminde öğretmenlerin yöntem seçiminde ve öğrenci aktifliğini sağlamada sorun yaşadıklarını ortaya koyan bulguları desteklemektedir.

Alınyazında çok çeşitli öğretme-öğrenme yöntem ve tekniklerinden söz edilmekte olup her birinin taşıdığı özellikler, kullanım amaç ve koşulları farklı olduğu belirtilmektedir. Bu nedenle her durumda ayn yöntemi kullanmanın başarı sağlaması düşünülemez. Bilen (2006) ve Demirel (2006)'e göre öğretme-öğrenme sürecinde kullanılmak üzere yöntem ve tekniklerin seçimi yaparken her birinin taşıdığı özellikler ve kullanım amaçları, hedeflerin (kazanım) nitelikleri, içeriğin yapısı ve düzeyi, öğrenci ve öğretmenin eğitimden, beklentileri ve kendi kişisel özellikleri, süre, maliyet, kullanım kolaylığı, öğrenci sayısı, derslik ve büyüklüğü vb. çok sayıda değişken dikkate alınarak karar verilmesi vurgulanmaktadır. Bu çalışmada ise öğretmenin her öğrenme alanı, her kazanım, her durum vb. kısaca her koşulda ayn yöntemler sonucu elde edilmiştir. Nitekim öğretmenin yıllık planında tüm düzeylerdeki kazanımlar ve tüm öğrenme alanlarında aynı yöntem ve tekniklerin isimlerinin yazılı olması bu kanıyı güçlendirmektedir.

MEB (2018) SBDÖP “...bilgiyi üreten, hayatta işlevsel olarak kullanabilen, problem çözebilen, eleştirel düşünen, girişimci, kararlı, iletişim becerilerine sahip, empati yapabilen, topluma ve kültüre katkı sağlayan vb." Niteliklerdeki bir bireyi tanımlamaktadır. Bu niteliklere sahip bireylerin yetişmesi için salt bilgi aktaran bir yapıdan ziyade bireysel farklılıkları dikkate alan, değer ve beceri kazandırma hedefli, sade ve anlaşılır bir program anlayışından ve uygulamalarından söz ederek öğretmende özgün ve yaratıcılık beklendiği vurgulanmaktadır. Bu beklentileri karşılamak amacinda olan öğretmeöğrenme etkinlikleri yaşantıya dayalı, uygulamaya dönük, canlı ve zevkli bir ortam sağlama, öğrenci ihtiyaçlarını karşılama, zengin bir çeşitliliğe sahip bireysel farklılıkları geliştirici vb. (Bilen, 2010) özellikler taşıması beklenirken; 
bu çalışma sürecindeki öğretmenin sınıfa ders öncesinde hazırlık yapmadan geldiği, öğrencilere konuyu özetli soru bankası kitabından okuyarak yazdırdığı gözlenmiş ve öğrencilerin bir konuyu tam olarak anlayamadan öğretmen tarafından başka bir konuya geçildiği yargısına ulaşılmıştır. Genel olarak öğretme öğrenme sürecinde öğrencilerde gözlenmesi beklenen "diğer derslerle ilişki kurması, örnek olaydan yararlanması, derse etkin olarak katılması, üst düzey düşünme becerilerini gerektiren sorulara cevap vermesi, işbirliğine dayalı grup çalışmaları yapması, düşüncelerinin ifade etmesi ve sürece yönelik bireysel değerlendirmeler vb. etkinlikler ise gözlenememiştir. $\mathrm{Bu}$ kapsamda ele aldığında incelenen eğitim durumlarının genel olarak Sosyal Bilgiler programının amaç ve beklentileri, özellikle de "öğrenmeyi öğrenme" sosyal ve vatandaşlıkla ilgili yetkinlikler başlığı altında tanımlanan nitelikleri kazdırması beklenmemelidir.

Yıllık planda 4 hafta (12 ders saati) olarak planlanan öğrenme alanının öğretim süreci; sınıf ortamındaki uygulamalarda 6 hafta (18 ders saati) sürmesinin en temel sebebinin gözlemci anekdotlarına göre öğretmenin ders süresini çok iyi yönetememesi (bazı derslere geç kalması, gereksiz ayrıntılarla ve konu dışındaki ilgisiz konularla çok zaman kaybetmesi) nedeniyle konuları zamanında yetiştirememesi olduğu sonucuna ulaşılmıştır. Öte yandan öğretmenin kendisiyle görüşüldüğünde ise program uygulamaları için zamanın yetersizliğini vurgulamıştır. Alanyazında da "zaman yetersizliği" ve "zamanın artırılma önerisi" çok sayıda araştırma tarafından dile getirilse de (Çalışkan, 2010; Karacaoğlu ve Acar 2010; Ekinci, 2007; Kabapınar ve Ataman, 2010; Kalaycıoğlu, 2007; Kuyucu, 2007 ; Taş ve Kıroğlu, 2018) aslında öncelikli sonunun zamanı "etkili ve verimli" kullanma olduğu düşünülmektedir.

Öğretmenin; öğrencilerinin nitelik ve beklentilerinin düşük olduğunu, sınav odaklı ve test mantığında düşündüklerini, bilgileri günlük yaşama geçiremediklerini, farklı düşünme, tartışma, yorumlama, örneklendirme, ilişkilendirme vb. zihinsel süreç etkinliklerinde iyi olmadıklarını, az bilgiyle yetinme çabası içinde olduklarını iddia etmesine rağmen, gözlem sürecindeki uygulamalarda bunları iyileştirecek önlemler almaması dikkat çekici bulunmuştur. Ayrıca öğrenci niteliklerinin olumsuzluğundan söz eden öğretmen, öğrencilerin istenen bir etkinliği, işi yapmada istekli olduklarını belirtmesine rağmen, öğrencinin bu "etkinlik isteğini", "eğlenme beklentisini" öğretim 
yöntemleri ile karşılanmıyor olması da düşündürücü bulunmuştur. Bu durum (Akpınar ve Gezer, 2010; Fırat Durdukoca, 2018; Ünal, 2012)'in öğretmenlerin öğrenen merkezli yeni eğitim yaklaşımlarını, fikir olarak benimsediklerini, ancak öğretim süreci uygulamalarına bunu yansıtmayarak ağırlıklı olarak geleneksel anlatımla ders işlemeyi sürdürdükleri sonucu ile örtüşürken; Ekinci (2007) ve Yaşar (2005)'ın ulaştığı “öğrenci merkezli yapılandırmacı uygulamalarda öğrencilerin neyi ne zaman öğreneceklerine kendilerinin karar vermeleri gerekirken süreci öğretmenlerin yönettikleri, öğrenciye yeterince seçme şansı tanınmadığı yargısını kanıtlar niteliktedir. Buna karşılık (Gültekin, Gürdoğan-Bayır ve Göz, 2013; Kösterelioğlu ve Özen, 2015)' in yapılandırmacı anlayışa dayalı SBDÖP değişikliğinin programın öğretme-öğrenme öğesini olumlu etkilediği ve öğretmenler tarafından genel olarak başarılı bir şekilde uygunabildiğine yönelik bulguları desteklememektedir.

Sosyal Bilgiler dersinde öğrenme ortamının, gerçek yaşam ilişkili ve anlamlı olması için bu dersin öğretme-öğrenme sürecinde, benzetimler yoluyla, gerçek ve güncel deneyimlerin gerekliliğine (Ersoy ve Kaya, 2009) dikkat çekilmektedir. Buna paralel olarak hem öğrencinin konuları günlük yaşamla ilişkilendirmesi bekleyen hem de gözlemlerine göre günlük yaşamdaki öğrenmelerin etkililiğini vurgulayan bir öğretmenin, bu amaca yönelik etkinlikler yapmaması ve "derslerin sadece sinıfta kaldığını" söylemesi oldukça dikkat çekici bulunmuştur. Öğrenilen konuları günlük yaşamla ilişkilendirme ve öğrenmenin niteliği yükseltme konunda beklentileri olan bir öğretmenin, derslerini anlatım, açklama, soru cevap, tekrar, test sorusu çözme, ders kitabı vb. geleneksel bir şekilde yürütmesi, öğrencilerin kitaptaki bilgileri aynen tekrar etmesini, kitaba bağlı kalmasını, test sorusu çözmesini istemesi de düşündürücü diğer hususlar olarak gözlenmiştir. Yanpar'a (2005) göre Sosyal Bilgiler derslerinde, yeterli düzeyde uygulama basamağında öğretim etkinlikleri yapılmadığı için öğrenilenlerin yaşamla ilişkilendirilmesinde güçlükler yaşanmaktadır. Öte yandan ulaşılan bu sonuç Gültekin, Gürdoğan-Bayır ve Göz (2013)'ün öğretme-öğrenme etkinliklerini öğrenci düzeyine uygun ve öğrenci merkezli bulduğu, kazanımlar ve konuların ise yaşamla ilişkisine dikkat çekildiğini ortaya koyan bulguları ile uyuşmamaktadır. EVÖA öğretme-öğrenme sürecinin özelinde ise Genç ve Çelik, 2018; Çolak 2015) öğretmen ve öğrencilerin vatandaşlık eğitimi içerik ve uygulamalarını eksik ve yetersiz gördükleri, bu eğitimin öğrencide kalıcı davranış 
değişimi açısından etkili olmadığı yönündeki bulgularla paralellik gösteren etkinlik ve uygulamalar olarak değerlendirilmektedir. Ancak buna karşılık İkinci (2016) çalışmasında öğretmenlerin vatandaşlık konularının öğretiminde aktif öğretim yöntemlerini kullandıklarına ilişkin tespitlerden söz etmektedir.

Öğretim materyalleri kullanma açısından kendisiyle yapılan görüşmede okulun materyal yetersizliği olmasına rağmen derslerinde düz anlatıma dayalı somutlaştırma, şarkı, şema, benzetme, puzzle kullanma, özet fotokopileri verme, EBA ve akıllı tahtadan yararlandığını, ders kitabı yerine de sınavlara yönelik konu özetli soru bankası kullandığını söylemektedir. Ancak gözlem bulgularına göre öğretmenin EVÖA kazanımlarına yönelik etkinliklerinin büyük bir çoğunluğunda "orta derecede yeterli ile çok yetersiz" arasında değişen yeterlik düzeylerinde sadece "konu özetli soru bankası ders kitabı ve yazı tahtası" kullandığı; çok nadiren de akıllı tahtadan yararlandığı, bunların dışında hiçbir materyal kullanmadığı belirlenmiştir. Elde edilen bu bulgular Akpınar, Çolak ve Yiğit (2012); Yeşil (2016)'in öğretmen ve öğretmen adaylarının öğretim sürecindeki yöntem teknik seçimi ve kullanma, materyal kullanma, iletişim ve sınıf yönetimi boyutlarında tespit ettikleri yetersizlikleri desteklemektedir. Aynı zamanda ortaya çıan göstergeler Doğanay ve Sarı (2008) tarafından ileri sürülen öğretim programının uygulanmasında gerekli olan aile, toplum, araç-gereç, fiziki koşullar ve hizmet içi eğitim ihtiyacını yansıtır niteliktedir. Ancak Ayva (2010), bu sonuçların tersine Sosyal Bilgiler dersinin öğrenme öğretme sürecine öğrencilerinin aktif öğrenme yöntemleri ile katıldıkları çalışma yapraklarını olumlu bulduklarını sonucunu ortaya koymaktadir.

Öğretmenin yıllık planı da özellikle öğretim yöntem ve teknikleri ile öğretim materyallerinin yer aldığı bölümleri açısında işlevsel bulunmamış, bu bölümlerin sadece "liste" özelliği taşıdığı sonucuna ulaşılmıştır.

Özetle 2018 Sosyal Bilgiler öğretim programını genel olarak basit, somut, görsellik açısından zengin bulan öğretmenin, bu programın EVÖA kazanımları için öğretme-öğrenme süreci etkinliklerinde "öğrenci etkinliğine dayalı, daha çok duyu organını işe koşan, yaparak yaşayarak öğrenmeyi, bireysel farklılıkları esas alan, günlük yaşamla ilişkilendiren, ezberden çok anlamayı ve düşünce üretmeyi önemseyen vb. yaklaşımlar izlemediği gözlenmiştir. Dolayısıyla da bu çalışma ile incelenen öğretme-öğrenme süreci uygulamaları hem 2018 Sosyal Bilgiler öğretim programının vizyon, amaç ve 
ilkelerinden hem de çağdaş eğitim uygulama ve beklentilerini karşılamaktan oldukça uzakta olduğu sonucuna ulaşılmıştır. Bu kapsamda öğretim programlarındaki özellikle 2004 yılından itibaren, yapılandırmacı anlayış çerçevesinde öğrenci merkezli, öğrenilenlerin yaşama dönük olması, işbirlikli öğrenme, öğrenci aktifliği, vb. değişimlere rağmen; öğretme-öğrenme süreçlerindeki geleneksel öğretim zihniyeti ve yaklaşımlarını temsil eden uygulamalarda istenen düzeyde değişim olmadığı anlaşılmaktadır. Bu sonuçlar doğrultusunda özelde EVÖA kazanımları için öğretme-öğrenme süreci etkinliklerinde genelde ise SBDÖP’larının öngördüğü öğretme-öğrenme paradigma ve yaklaşımları açısından şu öneriler ileri sürülebilir:

- Öğretim programlarını hazırlamak, güncellemek ya da tamamen değiştirmek kadar onu hayata geçirecek öğretmenlerin de her anlamda öncelikle "hazırlanmasını" gerektirir. Bu süreçte öğretmenlerin özellikle programlarla getirilen yeniliklerin birer ihtiyaçtan kaynaklandığı ve belli bir amaca hizmet ettiği inancı özellikle benimsetilmelidir. Öğretmenin bu değişeme olan inancının yüksekliği programın gereklerini yerine getirmede daha üst düzeyde isteklilik ve verimlilik sağlayabilir.

- Öğretmenler gerek hizmet öncesinde gerekse çeşitli dönemlerde hizmet içinde aldıkları eğitimlerle kazandıklanı temel becerileri uygulamaya geçirme konusunda teşvik edici düzenlemelere yer verilebilir.

- Ayrıca her ders programlarının uygulanması için okul ya da birkaç komşu okul düzeyinde "dar bir çevrenin özellikleri ve ihtiyaçları" dikkate alınarak ekip çalışmaları sağlama yoluyla programların bütün yönleri ve daha nitelikli işe koşulması konusunda teknik destek ve rehberlik sağlanmalıdır.

- Yine öğretmenlik mesleğini yerine getirme konusunda öğretmeni geliştirici ve mesleki becerilerinin niteliğini artırıcı çeşitli denetim mekanizmaları devreye sokulmalıdır.

- Öğretmenin yetiştiği eğitim fakültelerinde de hem yeni program değişimlerini hayata geçirme hem de okullardaki uygulamalara cevap verecek nitelikte öğretme-öğrenme yaşantıları işe koşularak öğretmen adaylarının yaparak yaşayarak öğrenmesini sağlayıcı zengin ortamlar halinde düzenlenmelidir. 
EXTENDED ABSTRACT

\title{
Investigation of Educational Situations Related to Effective Citizenship Learning Area Achievements in 5th Grade Social Studies Course: A Case Study
}

\author{
Mustafa Yeler-Gürbüz Ocak \\ BurdurM. Akif Ersoy University-Afyon Kocatepe University
}

The multi-faceted changes in the individual and social life related to the phenomenon of globalization have made it necessary for all elements of the education system to be changed to meet the needs of the day, in particular the curricula which are the basic elements of the functioning of this system. One of the updated curricula within this scope is the Social Studies Curriculum. Social Studies can be defined broadly as an area that aims with an interdisciplinary understanding to get an individual to gain knowledge and skills in order that $\mathrm{s} /$ he can become active in every physical and social environment. "Sosyal Effective Citizenship" has been added for the first time as one of the learning areas that serve this purpose in the Social Studies curriculum renewed by Ministry of National Education (2017). It is foreseen that this learning area, which includes the relations between the state and the individual, rights and responsibilities, will be handled within the framework of constructivist understanding through teaching-learning activities that center the student.

The findings of some studies in the literature on the evaluation of social studies curriculum indicate that the changes made in the curriculum generally do not create the desired result or that these programs cannot be implemented properly. In addition, it was determined that these studies were mainly based on either teachers' or students' opinions or document analysis on Social Studies curriculum. From this point of view, it is seen that the practices in teaching-learning processes are not taken into consideration enough in the literature, and it is considered as an important deficiency. To this end, this study intends to investigate what was done in the teaching-learning process in order to attain the objectives regarding the Active Citizenship learning area in the 5th grade which was included in the Social Studies curriculum for the first time. It also aims to examine the 
application processes in the curriculum by observing the features of the activities in the classroom context through providing various data.

This case study was planned and conducted in order to examine the whole process of a course related to a specific learning area within its own unique conditions. Single case design was used to examine the various variables in the process in a holistic way through collecting multiple data on the activities in teaching-learning process of the selected learning area.

The data were collected by course observation, observer opinion, semistructured interview and document analysis. "Convenient sampling", one of the purposeful sampling methods, was applied in this study. So, the study group was the fifth-grade students of a secondary school where the majority of the students were in medium socioeconomic status in Burdur. There were 17 students, 14 girls and 3 boys, in this class. The data were analyzed in accordance with the characteristics of the data collection tools, and themes were defined.

In terms of teaching methods and techniques regarding the objectives, it was observed that mainly lecturing and question and answer method were used, but they could not be used adequately. Students' active participation could not be achieved, the method-technique selection did not take into account the levels of the objective in terms of target taxonomy, and student-centered activities were not performed.

As for teaching materials, it was revealed that the teacher depended mainly on the textbook, used the blackboard in order that the students can take notes and repeat what they learned, and rarely used the smart board for video display. It was determined that the teacher did not use material in the majority of the activities in the observation form.

The two main dimensions of teaching-learning processes, pre-course and course process themes, were obtained by examining the observers' own anecdotes -apart from the observation form- about the course of instruction during the six-week observation period. The course process theme is divided into sub-themes of teaching methods and techniques, teaching material, time management and communication-interaction. These themes showed that teacher mainly used straight lecturing and question-answer technique, mostly depended on the textbook, get the students write some of the information (regarding the subjects) from question bank books. It was found that the teacher used only question bank books 
with summary of the subjects and the blackboard in almost all courses. It was determined that the teacher benefited from the smart board, although rarely.

It was observed that much more time was used in Effective Citizenship learning area activities Effective Citizenship learning area activities, that the majority of the teaching techniques and materials mentioned in the plan were not used, that both the levels of acquisition were not taken into consideration in the selection of methods/materials and there were no diversity, and that the names of the same teaching methods and materials were written in other areas of learning in the annual plan.

The interview with the teacher of the course manifested a dilemma: while the teacher was aware of the fact that her students are in need of materials and games for courses, she was still in tendency to continue the practice of conventional and uniform understanding of teaching methodstechniques and materials.

It was concluded that the examined practices in the teaching-learning process are far from responding both to the vision, goals and principles of the 2018 Social Studies Program and to contemporary educational approaches and practices. In this sense, it was evaluated that despite the changes such as student-centered and cooperative learning, students' active participation and real life-oriented learning especially within the framework of constructivist approach from 2004 on, there is no desired level of change in the practices representing traditional teaching mentality and approaches in teaching-learning processes.

\section{Kaynakça / References}

Açıkgöz, K. (2003). Aktiföğrenme. İzmir: Eğitim Dünyası Yayınları.

Adanalı, K. ve Doğanay, A. (2010). Beşinci sınıf Sosyal Bilgiler öğretiminin alternatif ölçme değerlendirme etkinlikleri açısından değerlendirilmesi. Çukurova Üniversitesi Sosyal Bilimler Enstitüsü Dergisi, 19(1), 271-292.

Akpınar, B. ve Gezer, B. (2010). Öğrenen merkezli yeni eğitim yaklaşımlarının öğrenme -öğretme sürecine yansımaları. Dicle Üniversitesi Ziya Gökalp Eğitim Fakültesi Dergisi, 14, 1-12.

Akpınar, M. ve Bilgili, A. S. (2018). Sosyal Bilgiler 6. sını öğretim programı, kazanım, beceri ve kavram ilişkisi. Yüzüncü Yıl Üniversitesi Eğitim Fakültesi Dergisi, 15(1),855-882. 
Akpınar, M. ve Kaymakçı, S. (2012). Ülkemizde Sosyal Bilgiler öğretiminin genel amaçlarına karşılaştırmalı bir bakış. Kastamonu Eğitim Dergisi, 20(2), 605-626.

Akpınar, M., Çolak, K. ve Yiğit, E.Ö. (2012). Öğretmenlik uygulaması dersi kapsamında Sosyal Bilgiler öğretmen adaylarının yeterliklerine yönelik uygulama öğretmenlerinin görüşleri. M.Ü. Atatürk Eğitim Fakültesi Ĕ̆itim Bilimleri Dergisi, 36, 41-67.

Algan, S. (2008). İlköğretim 6. ve 7. sınıf Sosyal Bilgiler dersi öğretim programının ölçme ve değerlendirme öğesinin öğretmen görüşleri açısından incelenmesi. (Yayımlanmamış Yüksek Lisans tezi), Çukurova Üniversitesi, Sosyal Bilimler Enstitüsü, Adana.

Arslan, A. ve Demirel, Ö. (2007). İlköğretim 5. sınıf Sosyal Bilgiler dersi yeni öğretim programının değerlendirilmesi. Milli Ĕ̆itim Dergisi, 175, 198209.

Ata, B. (2007). Yeni Sosyal Bilgiler öğretmenliği lisans programının ilköğretim 2005 Sosyal Bilgiler dersi $(6,7$. sınıflar) öğretim programı açısından değerlendirilmesi.http://acikarsiv.gazi.edu.tr/index.php? menu=2Esecim $=10 \mathcal{E}$ YayinBIK=74\#

Aykaç, N. (2007). İlköğretim Sosyal Bilgiler dersi eğitim-öğretim programına yönelik öğretmen görüşleri. Elektronik Sosyal Bilimler Dergisi, 6(22), 4673.

Ayva, Ö. (2010). Sosyal Bilgiler dersi öğrenme öğretme süreci ile ilgili öğrenci görüşleri. International Conference on New Trends in Education and Their Implications, http://wwww.iconte.org/FileUpload/ks59689/File/58.pdf

Barr, R. D., Barth, J. L., and Shermis, S. S. (1977). Defining the social studies. Arlington, VA: National Council for the Social Studies.

Bilen, M. (2006). Plandan uygulamaya öğretim (6 baskı.). Ankara: Anı Yayıncılık.

Bilen, M. (2010). Öğretim ve öğretme yöntemleri. M. Bilen (Ed.). Eğitimde ilke ve yöntemler. İçinde (s.227-331). Ankara: Betik yayınları.

Büyüköztürk, Ş., Kılıç-Çakmak, E., Akgün, Ö.E., Karadeniz, Ş. ve Demirel, F. (2011). Bilimsel araştırma yöntemleri, (10.Baskı). Ankara: Pegem Akademi Yayıncılık.

Canerik, H. (2005). Sosyal Bilgiler programı ve öğretimi. Y. Kavak, E. Taşdemirci. (Ed). Eğitimde Yansımalar VIII. Yeni İlköğretim Programlarını Değerlendirme Sempozyumu (14-16 Kasım 2005, Kayseri). s.362-371. Ankara: Sim Matbaası. 
Çalışkan, H. (2010). İlköğretim altıncı ve yedinci sınıflar Sosyal Bilgiler programına ilişkin öğretmen görüşleri, Çă̆daş Eğitim Dergisi, 35, (377),3140.

Çetin, F. (2007). İlköğretim 4. sınıf Sosyal Bilgiler öğretim programının öğretmen görüşleri doğrultusunda değerlendirilmesi. (Meram İlçesi Örneği). (Yayınlanmamış Yüksek Lisans Tezi), Selçuk Üniversitesi, Konya.

Çoban, O., ve Akşit, İ. (2018). 2005 ve 2017 Sosyal Bilgiler öğretim programlarının öğrenme alanı, kazanım, kavram, değer ve beceri boyutları açısından karşılaştırılması. Journal of History Culture and Art Research, 7(1), 479-505. Doi:http:// dx. doi.org/10.7596/taksad.v7i1.1395

Çolak, K. (2015). Sosyal bilgiler ile vatandaşlık ve demokrasi eğitimi derslerinde küresel vatandaşlık eğitimi (Yayımlanmamış Doktora tezi). Marmara Üniversitesi.

Demirel, Ö. (2006). Öğretimde planlama ve değerlendirme "öğretme sanatı" (7b.). Ankara: PegemA Yayıncilık

Dinç, E. ve Doğan, Y. (2010). İlköğretim ikinci kademe Sosyal Bilgiler öğretim programı ve uygulanması hakkında öğretmen görüşleri. Sosyal Bilgiler Eğitimi Araştırmaları Dergisi, 1(1), 17-49.

Doğanay, A. (2008). Çağdaş Sosyal Bilgiler anlayışı ışığında yeni Sosyal Bilgiler programının değerlendirilmesi. Çukurova Üniversitesi Sosyal Bilimler Enstitüsü Dergisi, 17(2), 77-96.

Doğanay, A. ve Sarı, M. (2008). Öğretmen gözüyle yeni Sosyal Bilgiler programı: Adana ilinde bir araştırma. Illköğretim Online, 7(2). 468-484.

Döner, N. (2019). 2018 Sosyal bilgiler programı ortaokul müfredat değişikliği ve öğretmen görüşleri. (Yayınlanmamış Yüksek Lisans tezi). Balıkesir Üniversitesi Sosyal Bilimler Enstitüsü, Balıkesir.

Dumitriu, C. and Dumitru, G. (2014). Achieving citizenship education. a theoretical and experimental approach. Procedia- Social and Behavioral Sciences 149, 307- 311

Ekinci, A. (2007). İlköğretim Sosyal Bilgiler dersi öğretim programının yapılandırmacı yaklaşım bağlamında değerlendirilmesi. (Yüksek Lisans Tezi), Osmangazi Üniversitesi, Eskişehir.

Ersoy, A. F. ve Kaya, E. (2009). Sosyal Bilgiler dersi öğretim programının (2004) uygulama sürecine ilişkin öğrenci görüşleri. Kastamonu Ĕ̆itim Dergisi, 17(1), 71-86. 
Firat Durdukoca, Ş. (2018). Sınıf öğretmenlerinin Sosyal bilgiler dersi öğretim uygulamaları için öğretim tekniklerinin seçimine yönelik yeterlik algıları ve görüşleri. Türkiye Sosyal Araştırmalar Dergisi, 22(1), 211-242.

Genç, K. ve Çelik, H. (2018). Türkiye'deki vatandaşlık eğitiminin branş öğretmenlerinin bakış açılarıyla değerlendirilmesi. Sakarya University Journal of Education, 8(1), 126-138.

Gömleksiz, M. N. ve Bulut, İ. (2006). Yeni Sosyal Bilgiler dersi öğretim programının uygulamadaki etkililiğinin değerlendirilmesi. Kuram ve Uygulamada Eğitim Yönetimi Dergisi, 12(3), 393-421.

Gültekin, M., Gürdoğan-Bayır, Ö. ve Göz, N.L (2013). 2004 Sosyal Bilgiler öğretim programında yeni anlayışlar: 1998 öğretim programından farklılıkları açısından bir inceleme. Elektronik Sosyal Bilimler Dergisi, 12(46), 24-49.

Gündoğdu, A. (2010). Okul ve eğitim. Eğitime Bakış Ĕ̆itim Öğretim ve Bilim Araştırmaları Dergisi, 6(16), 1-2.

Gürbüz. S. ve Şahin, F. (2017). Sosyal bilimlerde araştırma yöntemleri. (4. Baskı) Ankara: Seçkin Yayınları.

İkinci, İ. (2018). Sosyal bilgiler öğretmenlerinin vatandaşlık algıları ve vatandaşlık eğitimi ile ilgili düşüncelerinin incelenmesi (Yayımlanmamış Doktora tezi). Dumlupınar Üniversitesi Eğitim Bilimleri Enstitüsü, Kütahya.

Kabapınar, Y. ve Ataman, M. (2010). İlköğretim Sosyal Bilgiler (4-5. sınıf) programlarındaki ölçme ve değerlendirme yöntemlerine ilişkin öğretmen görüşleri. İlköğretim Online, 9(2), 776-791.

Kalaycıoğlu, E. (2007). İlköğretim 4. ve 5. sınıf Sosyal Bilgiler programının öğretmen görüslerine göre değerlendirilmesi. (Yayınlanmamış Yüksek Lisans tezi). Atatürk Üniversitesi Sosyal Bilimler Enstitüsü, Erzurum.

Karacaoğlu, Ö. ve Acar E. (2010) Yenilenen Programların Uygulanmasında Öğretmenlerin Karşılaştığ1 Sorunlar. Yüzüncü Yıl Üniversitesi Eğitim Fakültesi Dergisi, 7(1), 45-58.

Kaya, A. (2008) Yapılandırmacı öğrenme yaklaşımını uygulayan sınıf öğretmenleri ile bu yaklaşımı uygulamayan dal öğretmenlerinin sınıf yönetimi yaklaşımlarının karşılaştırılması. (Yayınlanmamış Doktora tezi). İnönü Üniversitesi Sosyal Bilimler Enstitüsü, Malatya.

Kılıçoğlu, G. (2009). Sosyal bilgiler, dünyada ve ülkemizde gelişimi ve önemi. M. Safran. (Ed.), Sosyal bilgiler öğretimi içinde (s.4-16). Ankara: Pegem Akademi. 
Kösterelioğlu, İ. ve Özen, R. (2015).4. ve 5. sınıf Sosyal bilgiler ders programının eğitim durumu öğesinin değerlendirilmesi. Bolu örneği. Elektronik Ĕ̆itim Bilimleri Dergisi, 4(8), 111-126.

Kuyucu, D. (2007). İlköğretim Sosyal Bilgiler 5. sınıf öğretim programının uygulanmasının öğretmen görüşleri doğrultusunda değerlendirilmesi (Selçuklu İlçesi Örneği). (Yayınlanmamış Yüksek Lisans Tezi), Selçuk Üniversitesi, Konya.

MEB (2003). Eğitim öğretim çalışmalarının planlı yürütülmesine ilişkin yönerge. Tebliğler dergisi, 2551.

MEB (2004). Sosyal Bilgiler 4 ve 5. Sinıf öğretim programı. Ankara: Millî Eğitim Bakanlığı.

MEB (2015). Sosyal Bilgiler öğretim programı. Ankara: Millî Eğitim Bakanlığı. MEB (2017). Sosyal Bilgiler öğretim programı. Ankara: Millî Eğitim Bakanlığı.

MEB. (2012). İlköğretim kurumları (İlkokul ve ortaokul) haftalık ders çizelgesi. Millî Eğitim Bakanlığı Tebliğler Dergisi, 75(2658), 314-316.

MEB. (2017). https://ttkb.meb.gov.tr/meb iys dosyalar/2017 07/18160003 basin aciklamasi -program.pdf

Meydan, A. ve Öztürk, Ç. (2008). Sınıf öğretmenlerinin Sosyal Bilgiler öğretiminde uygulanan ölçme değerlendirme yaklaşımına ilişkin görüşleri. VII. Ulusal Sinıf Öğretmenliği Ĕ̆itimi Sempozyumu. (2-4 Mayıs 2008). Çanakkale Onsekiz Mart Üniversitesi, Çanakkale.

Miles, M. B. ve Huberman, A.M. (1994). Qualitative data analysis : an expanded sourcebook. (2nd Edition). Calif.: SAGE Publications.

Navarro-Medina, E. and De-Alba-Fernandez, N. (2015). Citizenship Education in the European Curricula. Procedia- Social and Behavioral Sciences 197, $45-49$.

NCSS (1994). Expectations of excellence: Curriculum standards for the social studies. Washington, DC: NCSS.

NCSS (2012). Creating Effective Citizens: A Position Statement of National http://www.socialstudies.org/sites/default/files/publications/se/6505/650511.html

NCSS, (2010). National Curriculum Standards for Social Studies: A Framework for Teaching, Learning, and Assessment. Erişim adresi:https://www.socialstudies.org/advocacy/toolkit

Ornstein A.C ve Hunkins, F.P. (2014). Eğitim programı temeller, ilkeler ve sorunlar. T. Babacan (çev.). A. Arı (Ed.), Program değerlendirme içinde (s.381-436) Konya: Eğitim Yayınevi. 
Özkan, A. (2016). Status of the usage of active learning and teaching method and techniques by social studies teachers. Universal Journal of Educational Research 4(7), 1553-1562.

Polat, F. (2006). İlköğretim 7.sınıf Sosyal Bilgiler öğretiminde öğretmenlerin kullandıkları yöntemler ve karşılaştıkları sorunlar. Yüksek Lisans Tezi), Gazi Üniversitesi Gazi Eğitim Enstitüsü, Ankara.

Safran, M. (2011). Sosyal bilgiler öğretimine bakış. B. Tay ve A. Öcal). (Ed.), Özel Öğretim Yöntemleriyle Sosyal Bilgiler Öğretimi içinde (ss.2-18). Ankara: Pegem Akademi Yayıncilı.

Sigauke A. T. (2012). Young people, citizenship and citizenship education in Zimbabwe. International Journal of Educational Development 32, 214-223.

Sönmez, V. (2007). Öğretim ilke ve yöntemleri. Ankara: Anı Yayıncilık.

Sönmez, V. (2008). Ĕ̆itim felsefesi. (8. Baskı) Ankara: Anı Yayıncılık.

Subaşı, M. ve Okumuş, K. (2017). Bir araştırma yöntemi olarak durum çalışması. Atatürk Üniversitesi Sosyal Bilimler Enstitüsü Dergisi, 21(2), 419-426

Tanrıseven, I. (2015). Öğretimde planlama. T. Yanpar Yelken ve C. Akay. (Ed.), (2. Baskı). Öğretim ilke ve yöntemleri içinde (s.77-108). Ankara: Anı Yayıncilık.

Taş, H. ve Kıroğlu, K. (2018).2017 İlkokul Sosyal Bilgiler dersi öğretim programının öğretmen görüşlerine göre değerlendirilmesi. İlköğretim Online, 17(2), 697-716.

Tay, B. (2017). 2005 Sosyal Bilgiler dersi öğretim programı ile 2017 Sosyal Bilgiler dersi taslak öğretim programının karşılaştırması. International Journal Of Eurasia Social Sciences, 8(27), 461-487.

Turan, S. (2019). 2018 Sosyal bilgiler öğretim programının disiplinlerarası yapısının incelenmesi. Sosyal Bilgilerde Yenilikçi Araştırmalar Dergisi, 2(2), 166-190.

Türnüklü, A. (2000). Eğitimbilim araştırmalarında etkin olarak kullanılabilecek nitel bir araştırma tekniği: Görüşme. Kuram ve Uygulamada Ĕ̆itim Yönetimi 24, 543-559.

Ünal, S. (2012). Sosyal bilgiler öğretmenlerinin tarih konularının öğretiminde kullandıkları öğrenci merkezli yöntemlerle ilgili karşılaştıkları sorunlar. (Yayınlanmamış Yüksek Lisans tezi). Çanakkale Onsekiz Mart Üniversitesi Eğitim Bilimleri Enstitüsü, Çanakkale. 
Willemse, T. M., Ten Dam, G., Geijsel, F., Van Wessum, L. and Volman, M. (2015). Fostering teachers' professional development for citizenship education. Teaching and Teacher Education, 49, 118-127.

Yanpar, T. (2005). Sosyal Bilgiler dersinde oluşturmacı yaklaşımda öğrencilerin etkinlik dosyalarını yordayan değişkenler. Kastamonu Eğitim Dergisi, 13(2), 513-526.

Yaşar, Ş. (1998). Yapısalcı kuram ve öğretme-öğrenme süreci. Anadolu Üniversitesi Eğitim Fakültesi Dergisi 8(1-2),68-75.

Yaşar, Ş. (2005). Sosyal Bilgiler programı ve öğretimi. Eğitimde yansımalar: viii yeni ilköğretim programları değerlendirme sempozyumu bildiriler kitabı içinde (s.329-342). Ankara: Sim Matbaası.

Yeşil, R. (2006). Sosyal Bilgiler öğretmenlerinin sınıf içi öğretme yeterlikleri. (Kırşehir Örneği). Ahi Evran Üniversitesi Kırşehir Ĕ̆itim Fakültesi Dergisi, 7(2), 61-78.

Yeşiltaş, E. (2006). Sosyal bilgiler fiziki coğrafya konuları öğretiminde araçgereç kullanımının öğrencilerin başarı düzeylerine etkisi. (Kars ili örneği). (Yayınlanmamış Yüksek lisans tezi). Kafkas Üniversitesi, Sosyal Bilimler Enstitüsü, Kars.

Yıldırım, A. ve Şimşek, H. (2011). Sosyal bilimlerde nitel araştırma yöntemleri. (8. Baskı). Ankara: Seçkin Yayıncılık.

Yin, R. K. (2017). Durum çalışması araştırması. Çev. İ. Günbayı. (3. Baskı). Ankara: Nobel yayınları.

\section{Kaynakça Bilgisi / Citation Information}

Yeler, M. ve Ocak, G. (2021). 5. sınıf sosyal bilgiler etkin vatandaşlık öğrenme alanı kazanımlarına ilişkin eğitim durumlarının incelenmesi: Durum çalışması. OPUS-Uluslararası Toplum Araştırmaları Dergisi, 18(39), 175-222. DOI: 10.26466/opus.834524. 